University of Nebraska - Lincoln

DigitalCommons@University of Nebraska - Lincoln

Integration of Palmer Drought Severity Index and remote sensing data to simulate wetland water surface from 1910 to 2009 in Cottonwood Lake area, North Dakota

\author{
Shengli Huang \\ ASRC Research and Technology Solutions \\ Devendra Dahal \\ Stinger Ghaffarian Technologies \\ Claudia Young \\ Earth Resources Technology \\ Gyanesh Chander \\ Stinger Ghaffarian Technologies, gchander@usgs.gov \\ Shuguang Liu \\ U.S. Geological Survey, sliu@usgs.gov
}

Follow this and additional works at: https://digitalcommons.unl.edu/usgsstaffpub

Huang, Shengli; Dahal, Devendra; Young, Claudia; Chander, Gyanesh; and Liu, Shuguang, "Integration of Palmer Drought Severity Index and remote sensing data to simulate wetland water surface from 1910 to 2009 in Cottonwood Lake area, North Dakota" (2011). USGS Staff -- Published Research. 549.

https://digitalcommons.unl.edu/usgsstaffpub/549

This Article is brought to you for free and open access by the US Geological Survey at DigitalCommons@University of Nebraska - Lincoln. It has been accepted for inclusion in USGS Staff -- Published Research by an authorized administrator of DigitalCommons@University of Nebraska - Lincoln. 


\title{
Integration of Palmer Drought Severity Index and remote sensing data to simulate wetland water surface from 1910 to 2009 in Cottonwood Lake area, North Dakota
}

\author{
Shengli Huang ${ }^{\mathrm{a}, 1}$, Devendra Dahal ${ }^{\mathrm{b}, 2}$, Claudia Young ${ }^{\mathrm{c}, 2}$, Gyanesh Chander ${ }^{\mathrm{b}, 2}$, Shuguang Liu ${ }^{\mathrm{d}, *}$ \\ a ASRC Research and Technology Solutions (ARTS), contractor to USGS EROS, 47914 252nd Street, Sioux Falls, SD 57198, USA \\ b Stinger Ghaffarian Technologies (SGT), Inc., contractor to USGS EROS, 47914 252nd Street, Sioux Falls, SD 57198, USA \\ ' Earth Resources Technology (ERT), Inc., contractor to USGS EROS, 47914 252nd Street, Sioux Falls, SD 57198, USA \\ ${ }^{d}$ U.S. Geological Survey (USGS) Earth Resources Observation and Science (EROS) Center, 47914 252nd Street, Sioux Falls, SD 57198, USA
}

\section{A R T I C L E I N F O}

\section{Article history:}

Received 9 March 2011

Received in revised form 2 August 2011

Accepted 7 August 2011

Available online 31 August 2011

\section{Keywords:}

Aerial photographs

Landsat

Palmer Drought Severity Index

Prairie Pothole Region

Remote sensing

Surface water

Wetland

\begin{abstract}
A B S T R A C T
Spatiotemporal variations of wetland water in the Prairie Pothole Region are controlled by many factors; two of them are temperature and precipitation that form the basis of the Palmer Drought Severity Index (PDSI). Taking the $196 \mathrm{~km}^{2}$ Cottonwood Lake area in North Dakota as our pilot study site, we integrated PDSI, Landsat images, and aerial photography records to simulate monthly water surface. First, we developed a new Wetland Water Area Index (WWAI) from PDSI to predict water surface area. Second, we developed a water allocation model to simulate the spatial distribution of water bodies at a resolution of $30 \mathrm{~m}$. Third, we used an additional procedure to model the small wetlands (less than 0.8 ha) that could not be detected by Landsat. Our results showed that i) WWAI was highly correlated with water area with an $\mathrm{R}^{2}$ of 0.90 , resulting in a simple regression prediction of monthly water area to capture the intra- and inter-annual water change from 1910 to 2009; ii) the spatial distribution of water bodies modeled from our approach agreed well with the water locations visually identified from the aerial photography records; and iii) the $\mathrm{R}^{2}$ between our modeled water bodies (including both large and small wetlands) and those from aerial photography records could be up to 0.83 with a mean average error of $0.64 \mathrm{~km}^{2}$ within the study area where the modeled wetland water areas ranged from about 2 to $14 \mathrm{~km}^{2}$. These results indicate that our approach holds great potential to simulate major changes in wetland water surface for ecosystem service; however, our products could capture neither the short-term water change caused by intensive rainstorm events nor the wetland change caused by human activities.
\end{abstract}

Published by Elsevier Inc.

\section{Introduction}

\subsection{Prairie Pothole Region and the wetlands}

The Prairie Pothole Region (PPR) of North America extends from north-central Iowa to central Alberta and covers an area of 715,000 $\mathrm{km}^{2}$ (Fig. 1), where there are millions of topographic depressional wetlands created by the last glacial retreat approximately 12,000 years ago (Fenneman, 1931). These wetlands are relatively small, lie within small isolated depressions, are generally underlain by glacial till of low permeability, and are embedded in a landscape matrix of natural grassland and agriculture (Winter \& Rosenberry, 1995). These wetlands vary from shallow and temporary to deep and permanent, depending on topography and the water balance (Fang \& Pomeroy, 2008; van der Kamp \& Hayashi, 2009). Most wetlands are shallow with depths generally less than $1 \mathrm{~m}$ and are small with an estimated median of

\footnotetext{
* Corresponding author. Tel.: + 16055946168.

E-mail address: sliu@usgs.gov (S. Liu).

${ }^{1}$ Work performed under USGS contract G08PC91508.

2 Work performed under USGS contract G10PC00044.
}

0.16 ha, $70 \%$ are 0.4 ha or smaller, and $83 \%$ are 0.8 ha or smaller (Sethre et al., 2005; Zhang et al., 2009). Wetlands in the PPR can contain water over time varying from days to years, but temporary and seasonal wetlands maintain surface water less than three months (Stewart \& Kantrud, 1971). The natural landscape of the PPR has been substantially filled, leveled, drained, and converted to agriculture since European settlement in the late $1800 \mathrm{~s}$, resulting in the loss of over half of the original 8 million ha of wetlands (Dahl \& Johnson, 1991; Euliss \& Mushet, 1996).

Spatiotemporal climate variation and the corresponding drought/ deluge cycle are common in the PPR and they affect the dynamics of PPR wetlands. The PPR is characterized by a dynamic continental climate and is well-known for its extreme and variable climate with high annual and regional variation in precipitation (Bragg, 1995; Woodhouse \& Overpeck, 1998). Variations in temperature and moisture content of competing air masses lead to great seasonal and annual differences in precipitation and evaporation rates, and strong north-south temperature and east-west precipitation gradients produce distinct regional climates. Climatic fluctuations drive hydrology, with atmospheric deposition, evaporation, and transpiration being the major components of the water balance of the wetlands and 


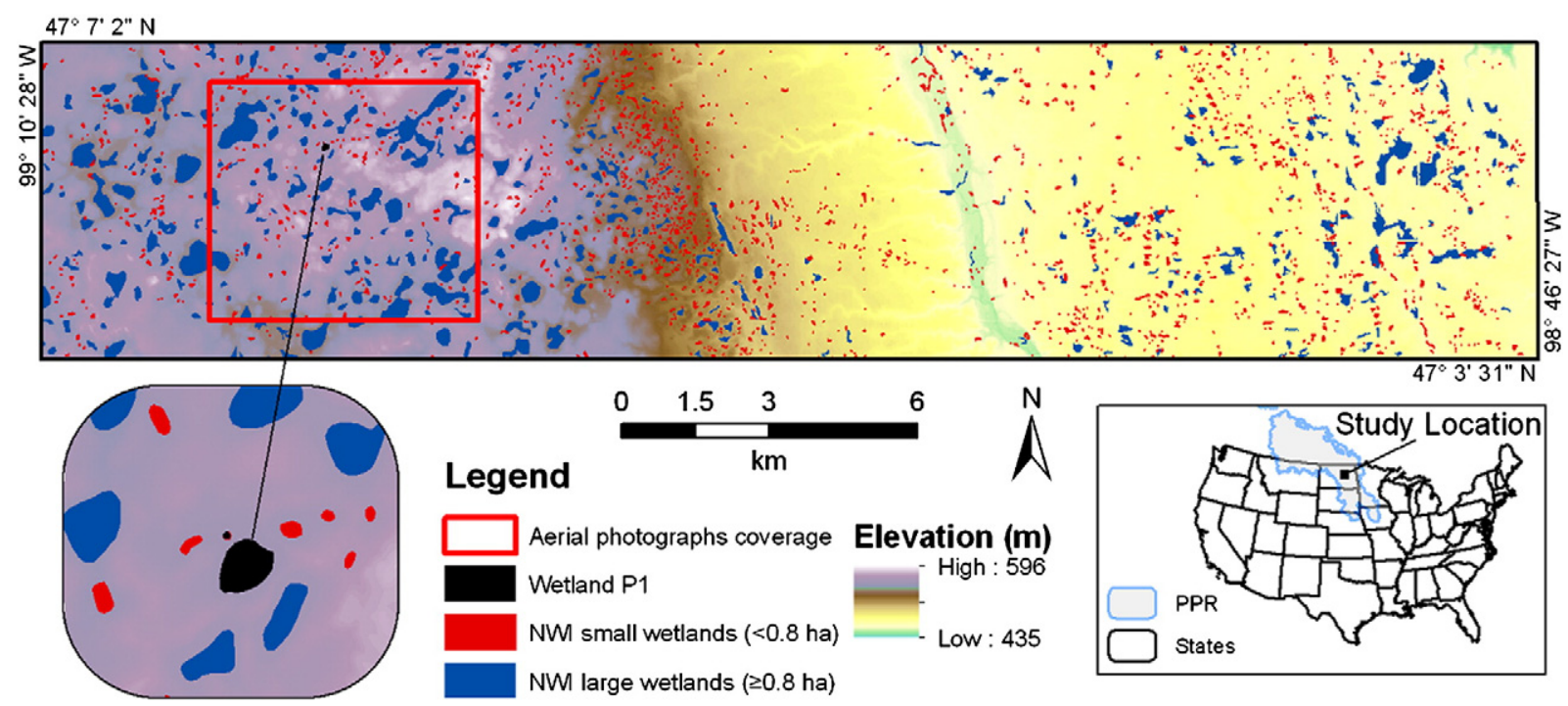

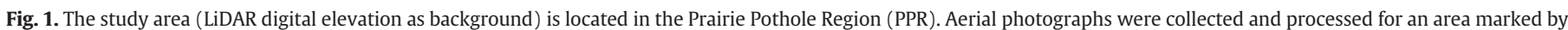
the red rectangle.

accounting for more than $60 \%$ of the variation in the number of wet basins (LaBaugh et al., 1998; Larson, 1995). Long-term cycles between periods of drought (Woodhouse \& Overpeck, 1998) and deluge (Winter \& Rosenberry, 1998) can persist for several years or even decades and determine the return time of the hydrological cycle (Diaz, 1983, 1986; Duvick \& Blasing, 1981; Johnson et al., 2005; Karl \& Koscielny, 1982; Karl \& Riebsame, 1984). Prairie wetlands are often dry during drought and fill to depths beyond the tolerance limits of most emergent vegetation during deluge (Winter \& Rosenberry, 1998).

Under a variable climate, water level fluctuation of the PPR wetlands is comprehensively determined by snowmelt, storm runoff, direct precipitation, evapotranspiration, seepage inflow, and outflow (Johnson et al., 2005; Millar, 1971). In spring, these basins receive extensive and rapidly melting water contributions from the in situ melt of accumulated snow, as well as an overland flow from precipitation upon the surrounding saturated uplands. During summer, the water balance of prairie wetlands is controlled by direct precipitation, lake evaporation, and wetland vegetation transpiration (Carroll et al., 2005; LaBaugh et al., 1998; Parkhurst et al., 1998; Winter \& Rosenberry, 1995), with evapotranspiration representing the single largest loss of water from most prairie wetlands (Rosenberry et al., 2004). When snowmelt or a rainstorm is significant, many usually-isolated (in terms of surfacewater) wetlands may connect to one another through the "fill and spill" mechanism (van der Kamp \& Hayashi, 2009; Winter \& LaBaugh, 2003). Deep groundwater flow in low conductivity till is very slow and has negligible effects on water balance for the PPR wetlands (van der Kamp \& Hayashi, 2009). Shallow ground water through shoreline seepage loss, however, accounts for a considerable portion of the water loss for small wetlands (Eisenlohr, 1966; Millar, 1971; van der Kamp \& Hayashi, 2009).

Along with water level fluctuation, inter- and intra-annual water surface change is a key factor in regulating many ecosystem services, including flood abatement, water quality improvement, biodiversity enhancement, carbon management, and aquifer recharge (Gleason et al., 2008). For wildlife conservation, the PPR is renowned for harboring large proportions of North American continental waterfowl populations (e.g., Batt et al., 1989). For floodwater mitigation, the antecedent water volume that already occupies the wetlands immediately prior to a flood event must be considered, which requires the continuous monitoring of wetland water dynamics (Gleason \& Tangen, 2008; Huang et al., 2011). For the emissions of major greenhouse gases (i.e., carbon dioxide, methane, and nitrous oxide) from wetland ecosystems, the soil water- filled pore space is the major factor for determining the anaerobic and aerobic condition (Gleason et al., 2009).

\subsection{Monitoring program issues and research objectives}

Due to the importance of the wetland water surface area in so many fields, the water dynamics of the PPR wetlands have been studied by many researchers. One approach measures water levels in wetlands and their surrounding catchments. This approach enables us to better understand the hydrological process and mechanism of water level fluctuations of individual wetlands, but it limits the number of wetlands that can be assessed; this reduces our ability to characterize wetland dynamics over broad spatial extents and under a variety of conditions (Niemuth et al., 2010; Rosenberry et al., 2004).

The second approach is to use satellite images, especially from Landsat, to map lake areas. Landsat time series allow for wetland change detection with different image processing methods such as density slice, maximum likelihood, and sub-pixel unmixing (Frazier \& Page, 2000; Ozesmi \& Bauer, 2002; Sethre et al., 2005; Work et al., 1974). For example, Beeri and Phillips (2007) used Landsat images from 1997 to 2005 to develop a model for detecting the seasonal advance and retreat of surface waters. However, several limitations exist when using Landsat data to create a Landsat-based monitoring program. First, Landsat images have a spatial resolution of 30-60 m, making it difficult to detect wetlands smaller than 0.4-0.8 ha (Ozesmi \& Bauer, 2002; Sethre et al., 2005; Work et al., 1974). Second, satellite records are only available since the 1970s, making interpretation of earlier history difficult. Third, satellite images are most desired in spring when prairie ponds generally reach their maximum water surface soon after snowmelt; however, during this same period cloud cover tends to be frequent, reducing the probability of a cloud-free day during the satellite overpass (Sethre et al., 2005). Short observational records, limited resolution, and a need for cloud-free images are three limitations of satellite observations (Liu \& Schwartz, 2011). Satellite-based monitoring approaches, like those of Zhang et al. (2009), could not quantitatively describe water transfers; therefore, the need for more quantitative approaches was emphasized by Liu and Schwartz (2011).

The third approach is to use aerial photographs to provide historical data on the occurrence of pothole lakes. With aerial photography at a scale of 1:24,000-1:25,000 from 1979 to 1994, the National Wetlands Inventory (NWI) datasets were created. The NWI datasets include wetland boundaries along with wetland regimes, but 
Table 1

Landsat datasets (Path 31, row 27) used in this study

\begin{tabular}{|c|c|c|c|c|c|}
\hline Date/sensor & Water $\left(\mathrm{km}^{2}\right)^{\mathrm{a}}$ & Date/sensor & Water $\left(\mathrm{km}^{2}\right)^{\mathrm{a}}$ & Date/sensor & Water $\left(\mathrm{km}^{2}\right)^{\mathrm{a}}$ \\
\hline 24 Jun 1984/TM & 5.39 & 16 Aug 1993/TM & 5.83 & 5 Aug 2002/ETM ${ }^{+}$ & 11.60 \\
\hline 14 Aug 1985/TM & 4.03 & 22 Jul 1994/TM & 6.25 & 12 May 2003/TM & 11.72 \\
\hline 14 May 1986/TM & 3.37 & 10 Aug 1995/TM & 9.42 & $9 \mathrm{Jul}$ 2004/TM & 12.83 \\
\hline 3 Jul 1987/TM & 5.52 & 22 Apr 1996/TM & 11.19 & 8 Jun 2005/TM & 12.04 \\
\hline 19 Jun $1988 / \mathrm{TM}$ & 5.25 & 14 Jul 1997/TM & 12.11 & 9 Sep 2006/TM & 9.56 \\
\hline 21 May 1989/TM & 4.52 & 3 Sep 1998/TM & 9.37 & 8 Jun 2007/TM & 9.67 \\
\hline 9 Jun 1990/TM & 3.63 & 12 Jul 1999/ETM ${ }^{+}$ & 11.10 & 13 Aug 2008/TM & 10.01 \\
\hline 14 Jul 1991/TM & 2.36 & 4 Jun 2000/TM & 11.39 & 1 Sep 2009/TM & 10.29 \\
\hline 2 Sep 1992/TM & 1.49 & 1 Jul 2001/TM & 10.63 & & \\
\hline
\end{tabular}

a Water surface area classified with maximum likelihood approach in study area of $196 \mathrm{~km}^{2}$ (see Section 4.1).

they do not reflect the wetland temporal change (Huang et al., 2011; Niemuth et al., 2010). In addition to NWI, the annual May waterfowl breeding population and habitat surveys were also based on aerial photographs. This survey, however, precluded inferences about how individual wetlands vary in time and space or as a function of water regime or local conditions because only the number of wetlands containing water was collected (e.g., Larson, 1995). Recently, Niemuth et al. (2010) reported their research on assessing the spatial and temporal patterns in wet areas for $\sim 40,000$ wetland basins that were sampled each May from 1988 to 2007 across portions of three states in the U.S. PPR. Niemuth et al. (2010) determined how inter-annual dynamics of wetlands were related to the water regimes. This recent work enabled us to better understand the spatial and temporal variation in wet areas; however, Niemuth et al. (2010) identified the following two shortcomings. First, intra-seasonal variation of persistent wet areas within the wetlands could not be inferred because the data were collected annually in May only. Second, the spatial patterns of wetness across broad space were interpolated from the survey data of 263-380 10.4-km² sampling blocks; therefore, the variance at the scale of individual wetlands or wetland complexes was not revealed. In general, even though high-resolution aerial photographs can be used for interpreting water surface accurately, they are spatially and temporally limited and are thus not practical for covering large areas.

Combining satellite and aerial photographs could improve the monitoring program. For example, Gilmer et al. (1980) investigated the statistical relation between aerial photographs and Landsat and found an approach that took advantage of Landsat's ability to gather information over a large area while using the capability of aerial photographs to detect small wetlands. Zhang et al. (2009) relied on Landsat and aerial photographs for lake size estimates and examined the power law relationships for different hydrological conditions for systems of thousands of pothole lakes. Based on the power law and aerial photographs from 29 July 1939, Zhang et al. (2009) reconstructed the distribution of pothole lakes in the summer of 1939 , which is near the end of the Dust Bowl drought.

Combining climate data could also improve field and remote sensing study for the PPR wetlands. Climate variables and wet-dry cycles were revealed to have good correlation with the field-measured water levels (van der Valk, 2005; Winter \& Rosenberry, 1998). The number of ponds was found to correlate with precipitation, temperature, and the number of wet basins counted from the previous May, as well as drought index and lag (e.g., Larson, 1995; Pospahala et al., 1974; Sorenson et al., 1998). Short-term climatic variation was revealed as the possible reason for the dramatic regional hydrologic differences in lake area fluctuations and in lake area response (Rundquist et al., 1987).

Considering the different shortcomings and complementary information from different data sources as summarized above, we sought to take the Cottonwood Lake area in North Dakota as a pilot study area to demonstrate the integration of long-term climate records and limited spatiotemporal remote sensing datasets to capture the time series change of water area for 100 years in both spatial and temporal dimensions. We aimed to simulate the dynamics of wetland water surface as well as model the spatial distribution of wetland complex, attempting to gain experience and lessons from this pilot study for extrapolating to the entire PPR. To do this, we combined Landsat images, aerial photographs, and a water balance index to develop a wetland water area index and used a regression method to model the water area change; we then modeled the water distribution, including small wetlands.

\section{Study area}

Our study area is a $6.4 \mathrm{~km} \times 30.6 \mathrm{~km}\left(196 \mathrm{~km}^{2}\right)$ block located in the Cottonwood Lake area, North Dakota (Fig. 1). Land cover and land use in 2008 included corn (14.0\%), small grains (7.6\%), soybeans $(24.9 \%)$, sunflowers (1.1\%), farmsteads (0.9\%), grassland (27.0\%), hayland $(7.2 \%)$, roads $(1.7 \%)$, trees $(1.7 \%)$, and wetland $(13.8 \%)$. The elevations in this study area range from 435.7 to $596.3 \mathrm{~m}$, with a mean elevation of $509.9 \mathrm{~m}$ and standard deviation of $43 \mathrm{~m}$. The western side of the study area features a more varied topography than the eastern side; the area is divided by a small low-elevation creek flowing from the northwest to the southeast. The study area is characterized by a mean annual precipitation of approximately $440 \mathrm{~mm}$, but seasonal and annual differences in precipitation and evaporation rates are substantial. More information of the study area can be seen from Huang et al. (2011).

\section{Datasets}

Twenty-six Landsat Thematic Mapper (TM)/Enhanced Thematic Mapper Plus $\left(\mathrm{ETM}^{+}\right)$scenes were collected for classifying surface water (Table 1). Eleven high-resolution aerial photographs were downloaded from http://earthexplorer.usgs.gov and http://www.nd.

Table 2

Eleven aerial photographs and one 17 May 2008 LiDAR dataset used in this study.

\begin{tabular}{|c|c|c|c|c|c|c|c|c|}
\hline Date & $\operatorname{Rain}^{\mathrm{a}}(\mathrm{mm})$ & Water ${ }^{\mathrm{b}}\left(\mathrm{km}^{2}\right)$ & Date & $\operatorname{Rain}^{\mathrm{a}}(\mathrm{mm})$ & Water ${ }^{\mathrm{b}}\left(\mathrm{km}^{2}\right)$ & Date & $\operatorname{Rain}^{\mathrm{a}}(\mathrm{mm})$ & Water ${ }^{\mathrm{b}}\left(\mathrm{km}^{2}\right)$ \\
\hline 30 Jul 1952 & 0 & 4.05 & 18 Jun 1984 & 16.00 & 3.58 & 15 Jul 2005 & 0 & 5.77 \\
\hline 26 May 1957 & 11.18 & 3.53 & 28 Jul 1990 & 30.56 & 1.96 & 13 Jul 2006 & 0.51 & 5.71 \\
\hline 8 Jun 1978 & 28.96 & 4.01 & 25 Sep 1997 & 0 & 5.96 & 17 May 2008 & 0.76 & 4.60 \\
\hline 16 May 1979 & 14.22 & 4.95 & 2 Jul 2004 & 0 & 5.78 & 23 Jun 2009 & 2.29 & 5.71 \\
\hline
\end{tabular}

a Rainfall within the preceding $96 \mathrm{~h}$ of acquisition.

b Water surface area was visually interpreted from aerial photographs in an area of $26 \mathrm{~km}^{2}$ (see red rectangle in Fig. 1 and Section 4.1 ). 


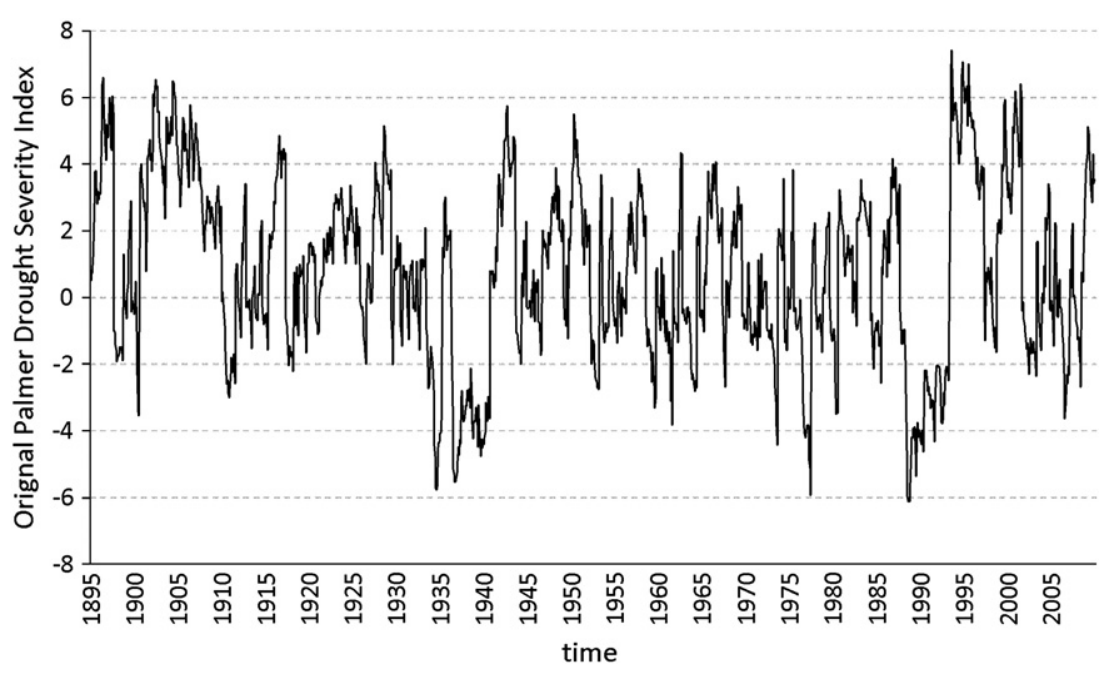

Fig. 2. Monthly original Palmer Drought Severity Index (PDSI) from 1895 to 2009 of the study area.

gov/gis/data-portal.html for visual interpretation on wetland water bodies (Table 2). The water detected from one Light Detection And Ranging (LiDAR) dataset (Huang et al., 2011) was also included (Table 2). NWI data were downloaded from http://www.fws.gov/ wetlands/.

Precipitation and temperature are two important factors of regional water balance, so we downloaded monthly Palmer Drought Severity Index (PDSI) of the North Dakota climate division 5 for 1895-2009 from the National Climate Data Center (http://www1.ncdc.noaa.gov/pub/ data/cirs/) (Fig. 2). The PDSI was originally developed by Palmer (1965) as a general methodology for evaluating soil moisture deficiency in each climate division. (The U.S. climate divisions are available at http://www. esrl.noaa.gov/psd/data/usclimate/map.html). PDSI is based on the supply-and-demand concept of the water balance equation, which takes into account precipitation and stored soil moisture (supply), potential evapotranspiration, water storage, and runoff (demand), as well as previous conditions (i.e., wetness in one month is related to the previous month). During this process, Palmer used a two-layer buckettype model for soil moisture computations, assuming that evapotranspiration occurs at the potential rate of Thornthwaite (1948) from the top soil layer until all the available moisture in this layer has been depleted. The PDSI typically falls in the range of \pm 4 , which defines the extreme drought $(-4)$ and extremely wet $(+4)$ thresholds of the index (Table 3). PDSI provides spatial and temporal representations of historical droughts; however, several drawbacks exist (Alley, 1984; Karl \& Knight, 1985). First, the two soil layers within the water balance computations and the assumption that no runoff is allowed to take place until the water capacity of the top soil layers is full are simplified and may lead to an underestimation of runoff. Second, it is sensitive to the available water content of a certain soil type, so applying the index for a

Table 3

Palmer Drought Severity Index ranges and classes.

\begin{tabular}{ll}
\hline PDSI range & Drought class \\
\hline 4.0 or more & Extremely wet \\
3.0 to 3.99 & Very wet \\
2.0 to 2.99 & Moderately wet \\
1.0 to 1.99 & Slightly wet \\
0.5 to 0.99 & Incipient wet spell \\
0.49 to -0.49 & Near normal \\
-0.5 to -0.99 & Incipient dry spell \\
-1.0 to -1.99 & Mild drought \\
-2.0 to -2.99 & Moderate drought \\
-3.0 to -3.99 & Severe drought \\
-4.0 or less & Extreme drought \\
\hline
\end{tabular}

climate division may be too general. Third, potential evapotranspiration is estimated using the Thornthwaite method, which although widely accepted is still an approximation. Fourth, the PDSI may have a late response to drought over several months because the data depend on soil moisture and its properties, which have been simplified to one value for each climate division. Fifth, snowfall, snow cover, and frozen ground are not considered in the index. All precipitation is treated as rain; therefore, there is no accountability for relative amounts of snow storage, resulting in the inaccurate timing of PDSI values in the winter and spring months (Dracup, 1991). Sixth, PDSI is designed for agriculture and thus does not accurately represent the hydrological impacts resulting from longer droughts. Finally, PDSI does not do well in regions where there are extremes in the variability of rainfall or runoff (Smith et al., 1993).

\section{Methodology}

With 26 Landsat images, 11 aerial photographs, and one LiDAR dataset in our study area, we first classified water features from Landsat images and aerial photographs (Section 4.1) and compared the original PDSI with Landsat-derived water area (Section 4.2). Subsequently, we developed a Wetland Water Area Index (WWAI) from PDSI (Section 4.3) and predicted and modeled the water distribution (Section 4.4). Since Landsat data cannot detect small wetlands, we gave special attention to modeling small wetlands (Section 4.5). Last, we combined all modeled wetlands to create final products (Section 4.6).

\subsection{Classifying water from remote sensing data}

We first georeferenced all Landsat images and converted the digital numbers of Landsat to at-sensor spectral radiance and top-ofatmosphere reflectance, with the method reported in Chander et al. (2009). We then calculated the Normalized Difference Vegetation Index (NDVI) using the Red (band 3) and the near-infrared (NIR, band 4) bands:

$\mathrm{NDVI}=(\mathrm{NIR}-\mathrm{Red}) /(\mathrm{NIR}+\mathrm{Red})$

NDVI is sensitive to the greenness of vegetation (Jensen, 1986). Next, we calculated the Normalized Difference Water Index (NDWI) using the Green (band 2) and the short wavelength infrared (SWIR, band 5) bands:

$\mathrm{NDWI}=($ Green - SWIR $) /($ Green + SWIR $)$ 

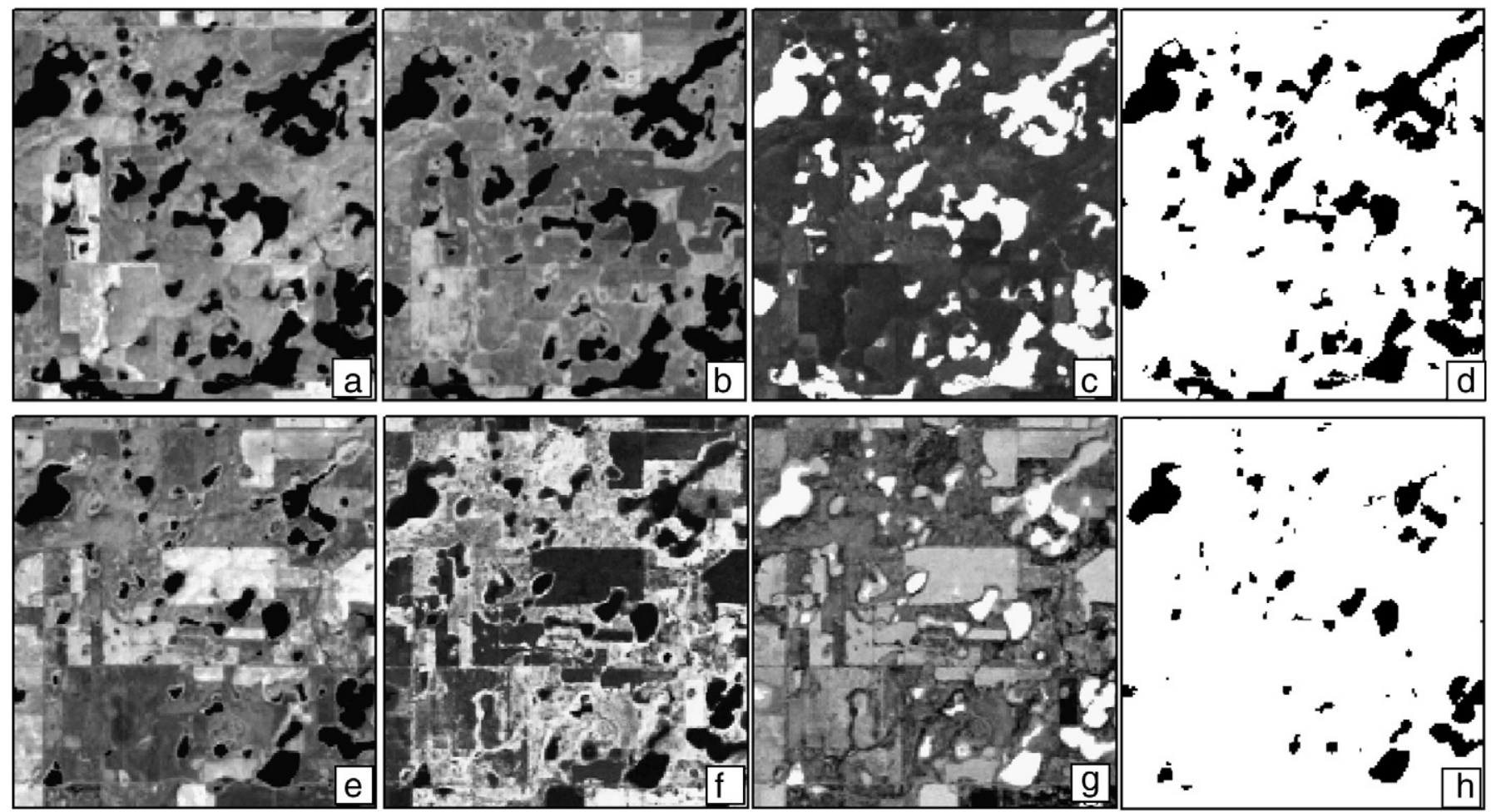

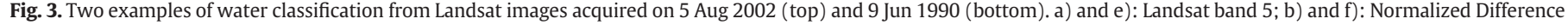
Vegetation Index; c) and g) Normalized Difference Water Index; d) and h): classified water. The area of the region is $4.8 \mathrm{~km} \times 5.3 \mathrm{~km}$.

NDWI is sensitive to surface water (Ji et al., 2009). Finally, we combined NDVI, NDWI, and the original 7 bands to classify water bodies based on supervised maximum likelihood classification (Hord, 1982) (Fig. 3). The water bodies detected from rivers were excluded. The high-resolution aerial photographs were carefully georeferenced and all the water bodies were visually interpreted and digitized.

\subsection{Initial comparison of Landsat-derived water area and PDSI}

To initially check whether PDSI was correlated with the Landsatderived water area, we compared Landsat-derived water area and PDSI data in one plot (Fig. 4). Fig. 4 showed that 1) from 1987 to
1992 when the PDSI was low, the Landsat-derived water area was also low; 2) from 1993 to 2000 and after 2009 when the PDSI was high, the Landsat-derived water area was also high. These results indicate PDSI contains useful information for water area modeling. However, we can also see that 1) the water area was low from 1982 to 1987 but high from 2001 to 2008, although the PDSI of these two periods was similar; 2) from 1988 to 1992, the PDSI increased but the water area decreased; 3 ) from 2001 to 2008 when the PDSI was at a relatively low level, the water area was quite high, especially obvious in 2001-2003. These results imply that there is a deficiency when using PDSI to estimate water area directly and a need to develop a better index using PDSI exists.

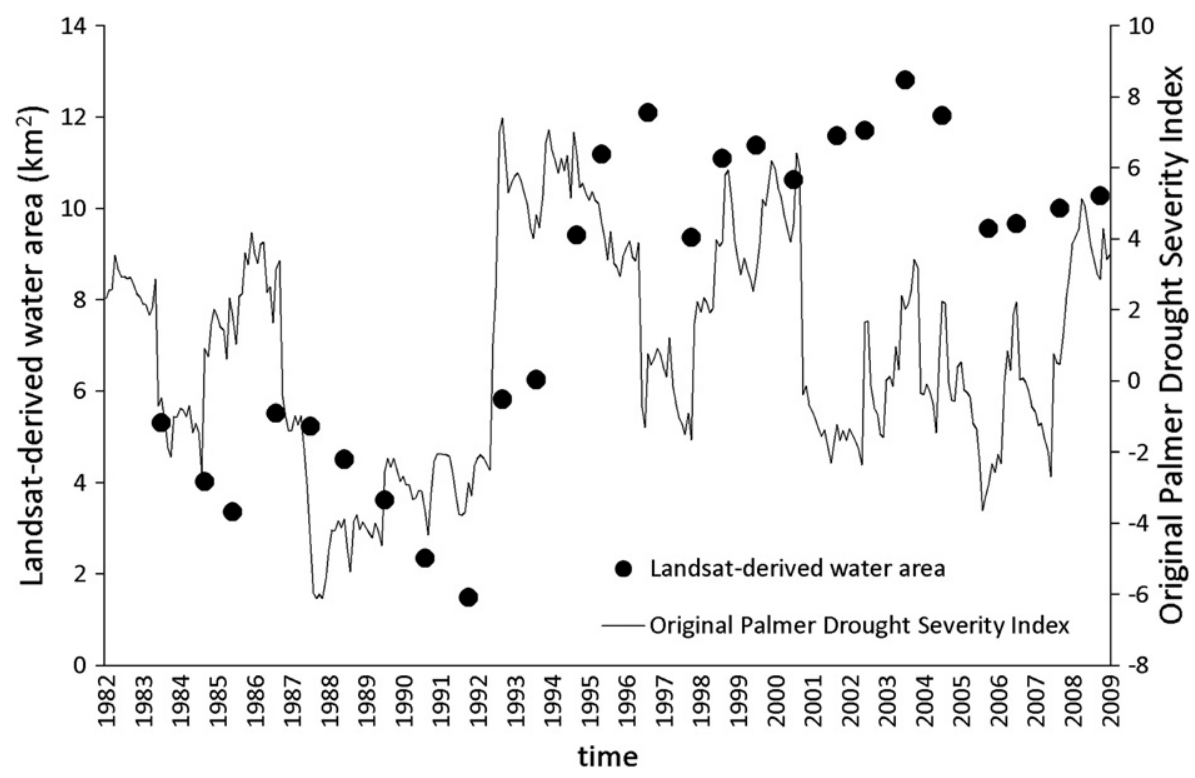

Fig. 4. The comparison of original monthly Palmer Drought Severity Index and Landsat-derived water area. 
From 1988 to 1992, all PDSI were negative ranging from -6 (extreme drought) to -2 (moderate drought) but with an increasing trend. The negative PDSI indicates more water loss than gain in terms of water balance, explaining why the water area decreased during this period. During the period of 2001-2003, most of the PDSI were low with a negative value; however, the water area was high. One explanation is that the antecedent water area was high and could affect the current water area; this agrees with Larson (1995), Zhang et al. (2009), and Niemuth et al. (2010), who stated that wetland water areas are dependent upon water availability over previous years, especially for large lakes. Therefore, cumulative PDSI (PdsiCum, Fig. 5) might be more useful for estimating water area. The PdsiCum was calculated as

PdsiCum $_{\mathrm{i}}=\sum_{n=1}^{i} \operatorname{PDSI}_{n}$

where i ranges from 1 to 1380 (i.e., total months from January of 1895 to December of 2009). In Fig. 5, the period of 1895-1909 was used for initial accumulation (i.e., spinning up) and thus ignored. After 1909, the cumulative PDSI (i.e., PdsiCum) had an increasing trend with a slope of 0.3323 . The PDSI incorporates both precipitation and temperature data in a reasonably realistic water balance model that accounts for both supply (rain or snowfall water equivalent) and demand (temperature transformed into units of water lost through evapotranspiration). Since PDSI is essentially a water-balance index, the cumulative PDSI (i.e., PdsiCum) trend should be even with a slope of zero from a long-term (e.g., over 100 years in our case) perspective. The slope of 0.3323 depicted in Fig. 5 might come from the deficiencies as summarized in Section 3 or from unknown reasons. Therefore, we subtracted the original since-1909 PDSI with a factor of 0.3323 to create a new drought index series (NewPDSI):

$\operatorname{NewPDI}_{\mathrm{i}}=\operatorname{PDSI}_{i}-0.3323$

Based on the time series of NewPDSI, a cumulative NewPDSI (NewPdsiCum, Fig. 5) was similarly produced with the following formula:

NewPdsiCum $_{\mathrm{i}}=\sum_{n=1}^{i}$ NewPDSI $_{n}$

The comparison of NewPdsiCum with Landsat-derived water area (Fig. 6) has a better agreement (when compared with Fig. 4) but still does not capture the temporal change well. This might be caused by PDSI drawbacks (Alley, 1984; Karl \& Knight, 1985). The PDSI is also imprecise in its treatment of all precipitation as immediately available rainfall (i.e., no snow accumulation on the ground), the effects of vegetation on surface evapotranspiration, the calibration coefficients, and some other processes (Dai et al., 2004). When the soil is frozen, or when snow accumulation and melting are significant, such as during the winter and spring months in our study area, PDSI has deficiencies (Dai et al., 2004). To improve the ability of PDSI in estimating water area, we developed a new Wetland Water Area Index (WWAI) from PDSI, as described in Section 4.3 below.

\subsection{Developing Wetland Water Area Index (WWAI)}

The PDSI was originally developed for agriculture drought monitoring. Considering the disadvantage of PDSI in wetland water area estimation, we used the new de-trended PDSI (i.e., NewPDSI) to develop a new index of WWAI with a flowchart shown in Fig. 7. This approach is essentially based on the cumulative PDSI concept.

In Fig. 7, three categories of "NewPdsiCum ${ }_{i}>550$ ", " $500 \leq$ NewPdsiCum $_{i} \leq 550$ ", and "NewPdsiCum ${ }_{i}<500$ " were created to roughly represent three periods of "high water", "normal water", and "low water" for antecedent water condition (see threshold values in Fig. 5). A weight $W$, ranging from 0 to 1 , was first calculated as

$$
\begin{aligned}
\mathrm{W}_{\mathrm{i}}= & \left(\text { NewPdsiCum }_{\mathrm{i}}-\text { Minimum NewPdsiCum }\right) \\
& \div(\text { Maximum NewPdsiCum }- \text { Minimum NewPdsiCum })
\end{aligned}
$$

The $\mathrm{W}$ indicates how far the antecedent conditions deviated from extreme dry/wet conditions. When the NewPdsiCum is close to the minimum, $\mathrm{W}$ is almost equal to zero and indicates that the antecedent condition is very dry. When the NewPdsiCum is close to the maximum, $\mathrm{W}$ is almost equal to one and indicates that the antecedent condition is very wet. Therefore, $\mathrm{W}$ could be used to adjust the influence of antecedent conditions on current water levels. 1) When NewPdsiCum $_{i}>550$, the wetland fills with a considerable amount of water. If NewPDSI $I_{i}$ is positive (NewPDSI $>0$ ), it could not increase the water surface correspondingly; therefore, we reduce the NewPDSI magnitude by multiplying " $\mathrm{a} *(1-\mathrm{W})$ ". In contrast, if NewPDSI $\mathrm{i}_{\mathrm{i}}$ is negative (NewPDSI $\leq 0$ ), the water surface could decrease quickly; therefore, we lowered the NewPDSI $\mathrm{i}_{\mathrm{i}}$ magnitude by subtracting " $\mathrm{b} * \mathrm{~W}$ ". 2) When NewPdsiCum $i \leq 550$, a very high NewPDSI $I_{i}\left(\operatorname{NewPDSI}_{i} \geq 4\right)$ indicates an extremely wet month, resulting in a possible significant

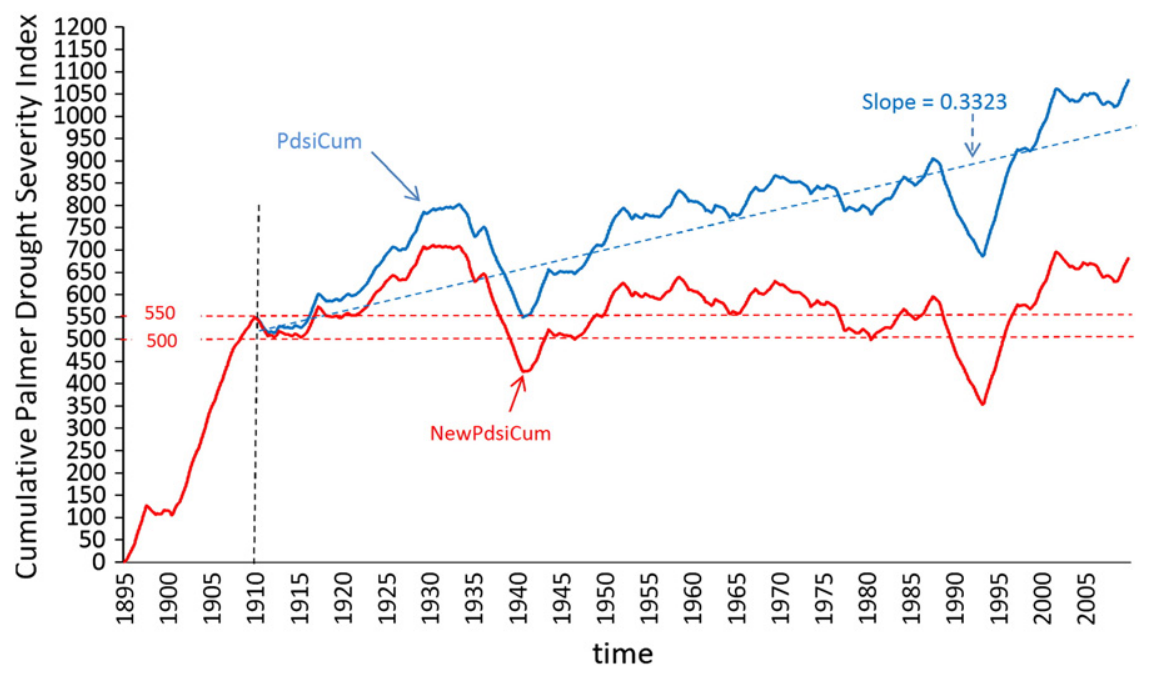

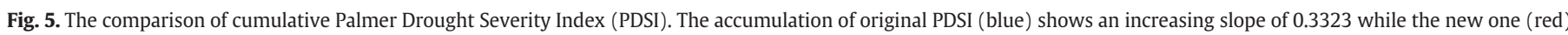
shows an even trend. 


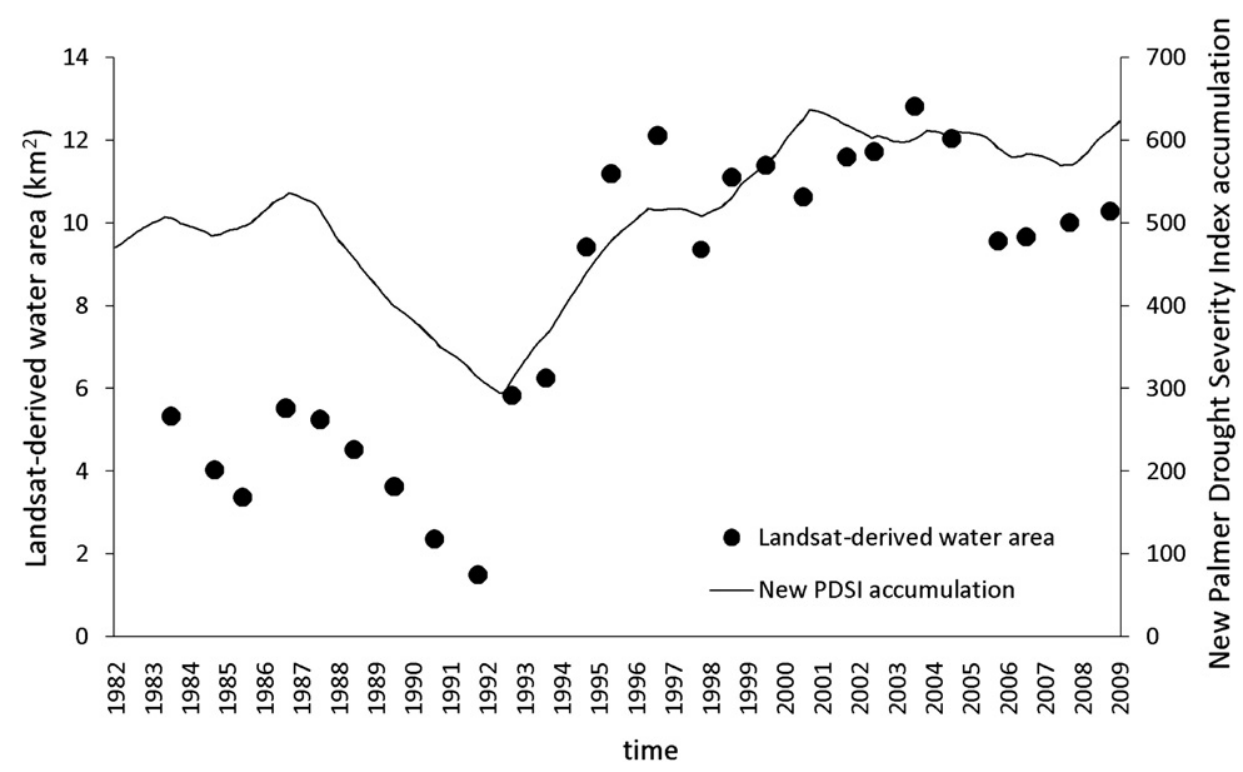

Fig. 6. The comparison of new Palmer Drought Severity Index accumulation and Landsat-derived water area.

runoff. In this case, we multiplied the part of "NewPDSI -4 " by 14 in order to consider the water amount contributed from surface runoff. The value 4 was subtracted to account for the water needed for soil infiltration before surface runoff contributed to the wetland water budget. The value 14 came from NWI datasets, which showed the upland catchment area is on average 14 times that of the wetland area. This contribution was further multiplied by the factor " $\mathrm{c} *(1-\mathrm{W})$ ", because a previous dry condition can attenuate the surface runoff contribution to the wetland water area whereas extended wet spells can increase open water area (LaBaugh et al., 1998; Johnson et al., 2004). In this step, we excluded winter months because precipitation that falls after the ground is frozen in the fall and before the spring thaw is more likely to remain as snow pack rather than melt to form surface runoff (Woo \& Winter, 1993). 3) When NewPdsiCum N $_{i}<500$, we subtracted NewPDSI $_{\mathrm{i}}$ with " $\mathrm{d} *(1-\mathrm{W})$ " to reflect the fact that more water is required for drought mitigation (e.g., soil infiltration and ground water recharge) and thus less water can be used for creating wetland open water areas. Taking these three points into account, we calculated a new index time series and then removed the trend to create the new accumulation as the final WWAI.

The model has four parameters (i.e., a, b, c, d) that required calibration. We assigned a value of 1 to these coefficients as initial condition. We made a series of simulations by iteratively changing individual values at a step of 0.1 . In each simulation, we computed the

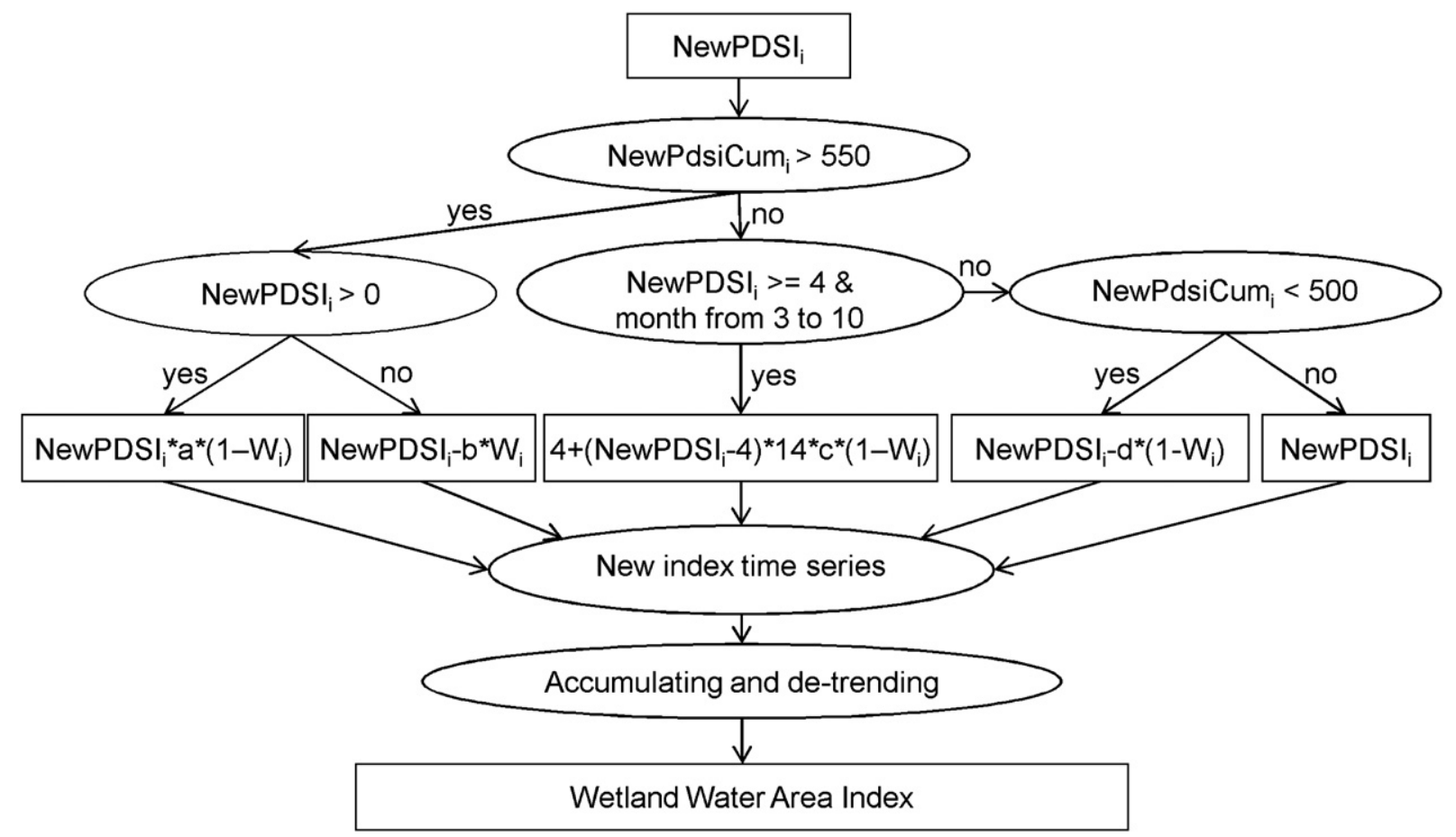

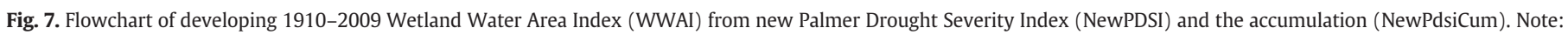
i) $W_{i}=\left(\right.$ NewPdsiCum $_{i}-$ Minimum NewPdsiCum $) /($ Maximum NewPdsiCum - Minimum NewPdsiCum); ii) Coefficients a $=1, b=2, c=1$, and $d=1.1$, see text. 
correlation of WWAI and Landsat-derived water area. This process was repeated until the maximum correlation was found and the temporal trend was visually satisfactory, resulting in the final acceptable parameters (i.e., $\mathrm{a}=1, \mathrm{~b}=2, \mathrm{c}=1$, and $\mathrm{d}=1.1$ ). The flowchart is shown in Fig. 7.

\subsection{Modeling water area and distribution}

When the Landsat-derived water area and WWAI are compared (Fig. 8), WWAI captured the water area very well in the temporal dimension. The $\mathrm{R}^{2}$ between WWAI and water area was up to 0.90 (Fig. 9), which indicates the WWAI can be used to predict the water area with high accuracy. Since we have monthly WWAI from 1910 to 2009, we estimated the monthly water surface area (WSA) for 100 years using Eq. 7:

$\mathrm{WSA}_{\mathrm{i}}=0.0177^{*} \mathrm{WWAI}_{\mathrm{i}}+0.0409$

where $\mathrm{WWAI}_{\mathrm{i}}$ is the Wetland Water Area Index for the month $\mathrm{i}$ of interest. However, only surface area but no spatial distribution can be modeled from this Eq. 7.

It is important to allocate the water area into spatial dimensions to capture both spatial and temporal dynamics for ecological application (e.g., Johnson et al., 2010) or hydrological study (e.g., Rover et al., 2011); thus, we developed an approach to model the spatial distribution for each month of 1910-2009 based on Landsat-derived water bodies through five steps. Taking July 1952 as an example, we first sorted the available 26 Landsat-derived water areas (see Table 1) from low to high. Second, we used the WWAI of July 1952 (383.15) and regression (i.e., Eq. 7) to model the water area as $6.82 \mathrm{~km}^{2}$. Third, we selected the two Landsat-derived water maps with water areas just smaller and greater than the area of $6.82 \mathrm{~km}^{2}$. In this case, they were the water maps of 22 July 1994 and 3 September 1998, respectively (see Table 1 ). We overlaid these two water body maps and labeled the water pixels that were detected on 22 July 1994, but not on 3 September 1998. Fourth, we excluded 2833 pixels from these water difference pixels using an "inward buffering" function in the Geographical Information System (GIS) (i.e., the outmost pixels were removed as a priority). The value of 2833 was determined by the area difference of 3 September $1998\left(9.37 \mathrm{~km}^{2}\right)$ and July $1952\left(6.82 \mathrm{~km}^{2}\right)$ divided by Landsat pixel size $\left(900 \mathrm{~m}^{2}\right)$. Finally, we merged the Landsat-derived water from 22 July 1994 and the remaining pixels to

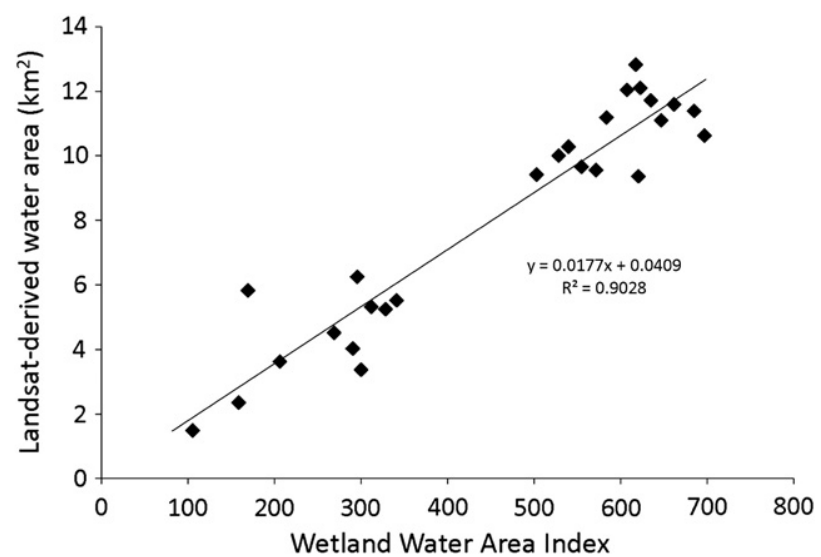

Fig. 9. Linear regression between Wetland Water Area Index and Landsat-derived water area. The sharp increase of water area from low to high water levels during 1993-1994 was represented by only two Landsat images (see Fig. 8), resulting in two dot populations in this plot.

create the water bodies for the month of July 1952. Fig. 10 shows the concept of spatial allocation.

\subsection{Modeling small wetlands}

Small and shallow wetlands differ from larger and deeper wetlands in their functions of warming, hydro-period, vegetation dynamics, nutrients mobilization, and waterfowl habitat; they also have high ecological value (Niemuth et al., 2010). However, due to the conventional spatial resolution of $30 \mathrm{~m}$, Landsat cannot reliably detect those wetlands smaller than 0.8 ha. With Landsat data rendering wetlands as just a few pixels, areas could be underestimated (Zhang et al., 2009). Therefore, we developed an approach to model small wetlands (i.e., those NWI polygons with areas less than $0.8 \mathrm{ha}$ ) based on baseline NWI datasets.

As explained above, we can predict the water area of a month of interest from WWAI and Eq. 7. This water area was divided by the constant total area of NWI wetland polygons to calculate a percentage (P), which could be greater than 1 during highly wet periods. For those small wetlands, the water-filled percentage, $\mathrm{P}_{\mathrm{s}}$, was calculated as " $P_{s}=P^{*} \beta$ ". When the month is between November and April (winter with low evaporation and early spring with snow melt), we assumed $\mathrm{P}_{\mathrm{s}}$

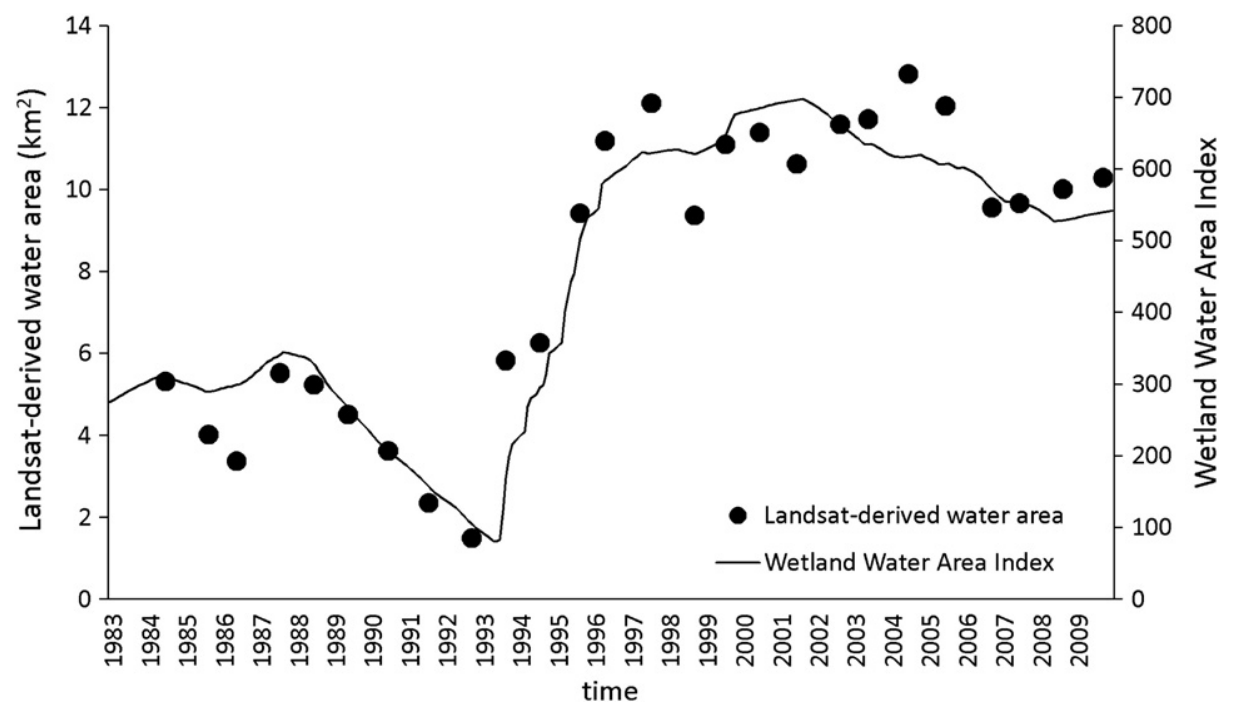

Fig. 8. The comparison of Wetland Water Area Index and Landsat-derived water area. 

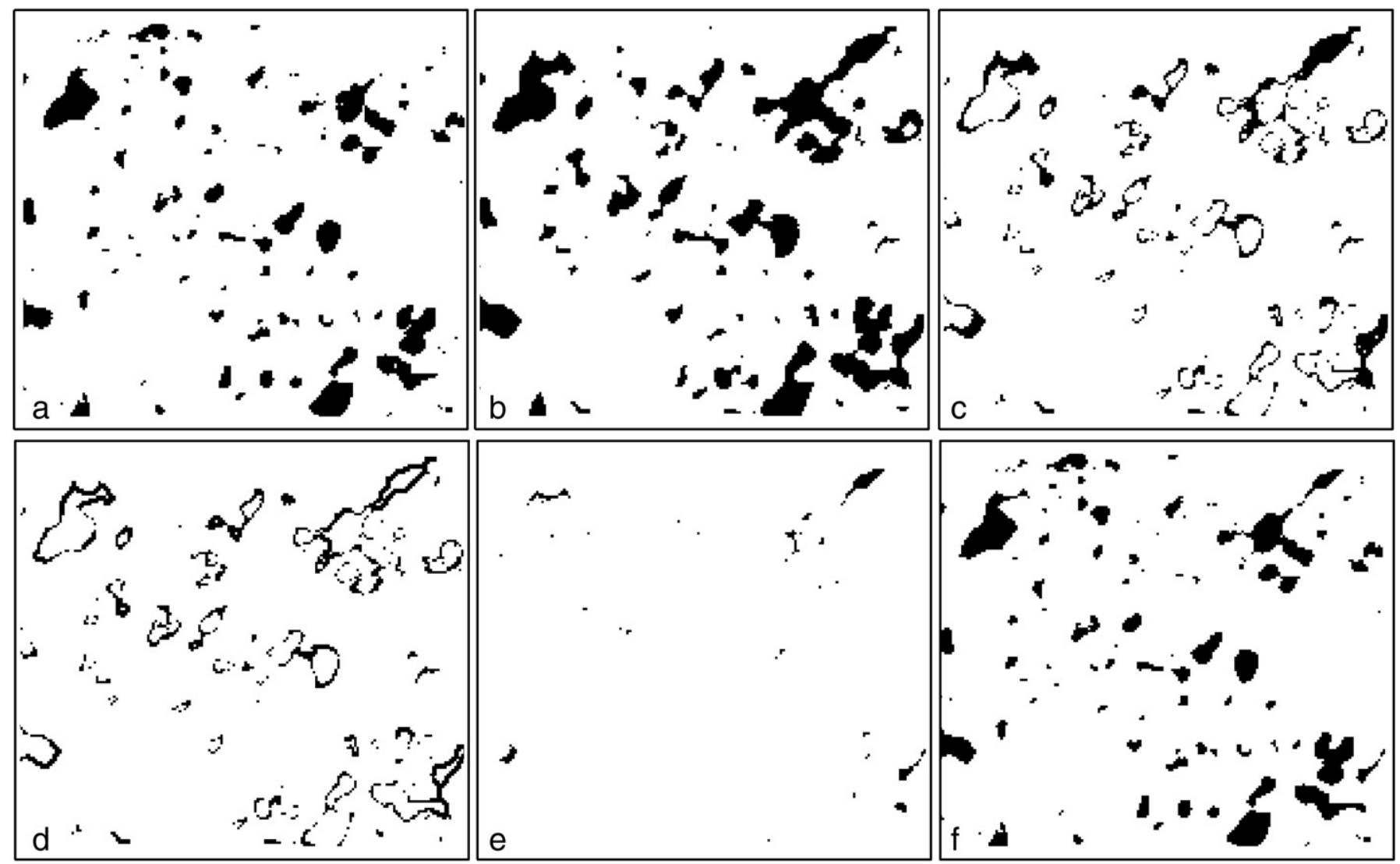

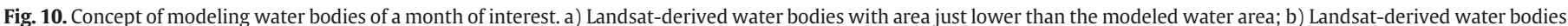

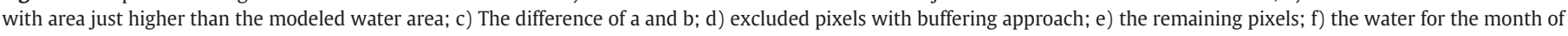
interest was created by merging a and e. The area of the region is $5.5 \mathrm{~km} \times 5.1 \mathrm{~km}$.

is equal to P. When the month is May to October, coefficient $\beta$ was empirically defined as:

$\beta= \begin{cases}0.00 & \left(\text { NewPDSI }_{i} \leq-4\right) \\ 0.30 & \left(-4<\text { NewPDSI }_{i} \leq-2\right) \\ 0.60 & \left(-2<\text { NewPDSI }_{i} \leq 2\right) \\ 0.75 & \left(2<\text { NewPDSI }_{i}<4\right) \\ 1.00 & \left(\text { NewPDSI }_{i} \geq 4\right)\end{cases}$

When NewPDSI $I_{i}$ is greater than or equal to 4 , runoff occurs and we assumed the same percentage for large and small wetlands (i.e., $P_{S}=P$ ). When NewPDSI $I_{i}$ is less than or equal to -4 , it indicates an extreme drought in the month; therefore, we assumed all the small wetlands dry up (i.e., $P_{s}=0$ ). When the temperature and evaporation rate rise dramatically from spring to summer, the area of smaller lakes declines to a much greater extent than for larger lakes (Zhang et al., 2009); therefore, we defined the coefficient $\beta$ ranging from 0 to 1 , depending on the corresponding NewPDSI ${ }_{i}$ value. The $\beta$ value was empirically determined by comparing $\mathrm{P}$, the NWI polygon area, and the area of small wetlands interpreted from aerial photographs. The concept of $\mathrm{P}_{\mathrm{S}}$ was similarly reported and applied by Niemuth et al. (2010). With this monthly $\mathrm{P}_{\mathrm{s}}$, small wetlands NWI baseline polygons were buffered to create new water bodies with an area of "NWI polygon area* $\mathrm{P}_{\mathrm{s}}$ " (Fig. 11).

\subsection{Modeling water area and distribution at landscape level}

The monthly wetland water bodies at the landscape-level were the combinations of all modeled wetlands, including those wetlands demonstrated in Fig. 10f and the small wetlands demonstrated in Fig. 11. Correspondingly, the monthly water area was calculated in GIS.

\section{Results}

We modeled the wetland water area for the $196 \mathrm{~km}^{2}$ study site for 1910-2009 (Fig. 12) using the input data from 26 Landsat scenes (Table 1), 11 aerial photographs and one LiDAR dataset (Table 2), and monthly PDSI data from 1895 to 2009 (Fig. 2). The water areas ranged from about 2 to $14 \mathrm{~km}^{2}$. The most striking difference within a short period is from 1993 to the early 2000s. Winter and Rosenberry (1998) reported that parts of the PPR experienced two extreme droughts during the last century: the Dust Bowl drought of the 1930s and a shorter one from 1988 to 1992 . Fig. 12 clearly shows the low water area in these two periods. The most significant wet period of the century beginning in 1993 (van der Valk, 2005; Winter \& Rosenberry, 1998 ) is also reflected by the high water areas in Fig. 12.

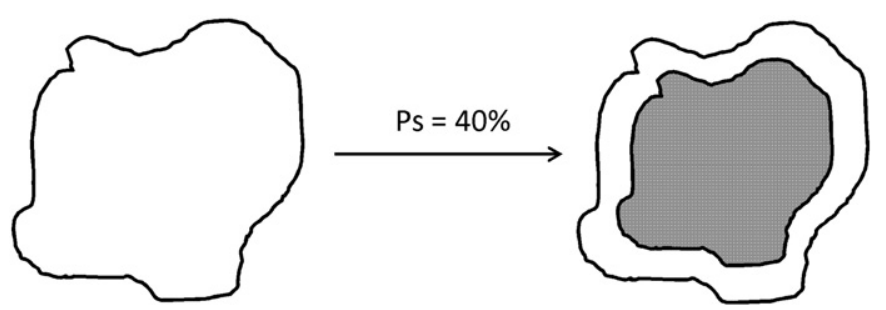

Fig. 11. Concept of buffering wetland NWI small polygon (left) to create water body (shaded polygon, right) with $\mathrm{P}_{\mathrm{S}}$ of $40 \%$. 


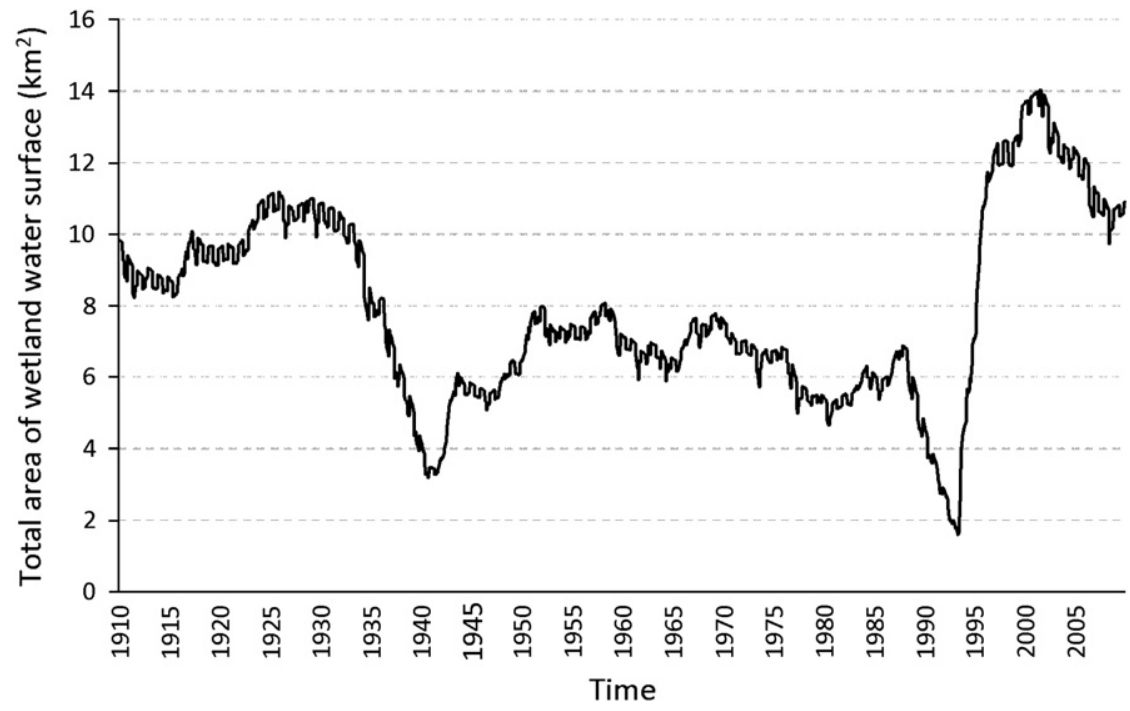

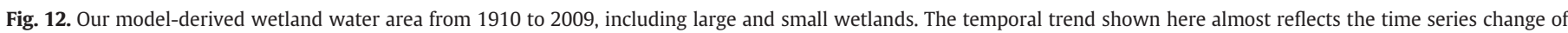
wetland water area index (WWAI).

The water levels of a semi-permanent wetland P1 (see Fig. 1) within our study area were measured since 1979 (Liu \& Schwartz, 2011). The comparison of our modeled wetland water area and the observed water levels (Fig. 13) shows the similar temporal change trend, indicating the reliability of our water area modeling. The spatial distribution between our modeled water and visually interpreted water also coincided well (Fig. 14). The contrast between the area extent of pothole lakes in 1990 and that in 2008 is striking. Many large pothole lakes shrank significantly during the drought period in the early 1990s but expanded greatly during the recent deluge period beginning in 1993.

We interpreted 12 water bodies from aerial photographs and LiDAR (Table 2), but only two of them are displayed as examples in Fig. 14. When all 12 water areas are compared, the $\mathrm{R}^{2}$ coefficient measures up to 0.83 with a mean average error of $0.64 \mathrm{~km}^{2}$ (Fig. 15). However, 11 of 12 water bodies were below the line $1: 1$ and the regression equation was $\mathrm{y}=0.865 \mathrm{x}$, indicating our modeled water area was underestimated. This bias could be attributed to at least two reasons. First, our approach was based on Landsat detection, which could lead to an underestimation of wetland water area, especially when the vegetations in the wetlands reduce the ability of Landsat to identify water (Rover et al., 2011; Sethre et al., 2005; Zhang et al., 2009). Second, our modeling time step of one month could capture the total amount of water balance during a 1-month period but did not capture the daily change. If there are considerable rainfall or snowmelt events before the specific dates of the aerial photographs (Table 2), the wetland could receive a significant amount of water and thus area extent could expand. Our model cannot capture this phenomenon. This could also be proved in Fig. 16, which shows the comparison of visually interpreted and modeled small wetlands (less than $0.8 \mathrm{ha}$ ). The modeled small wetlands on the three acquisitions (8 June 1978, 16 May 1979, and 18 June 1984) were underestimated when compared with aerial photographs and LiDAR. We expected that this underestimation might be caused by rainfall $(28.96,14.22$, and $16.00 \mathrm{~mm}$, respectively) just before the data acquisition (see Table 2), because small wetlands can increase rapidly as the result of a

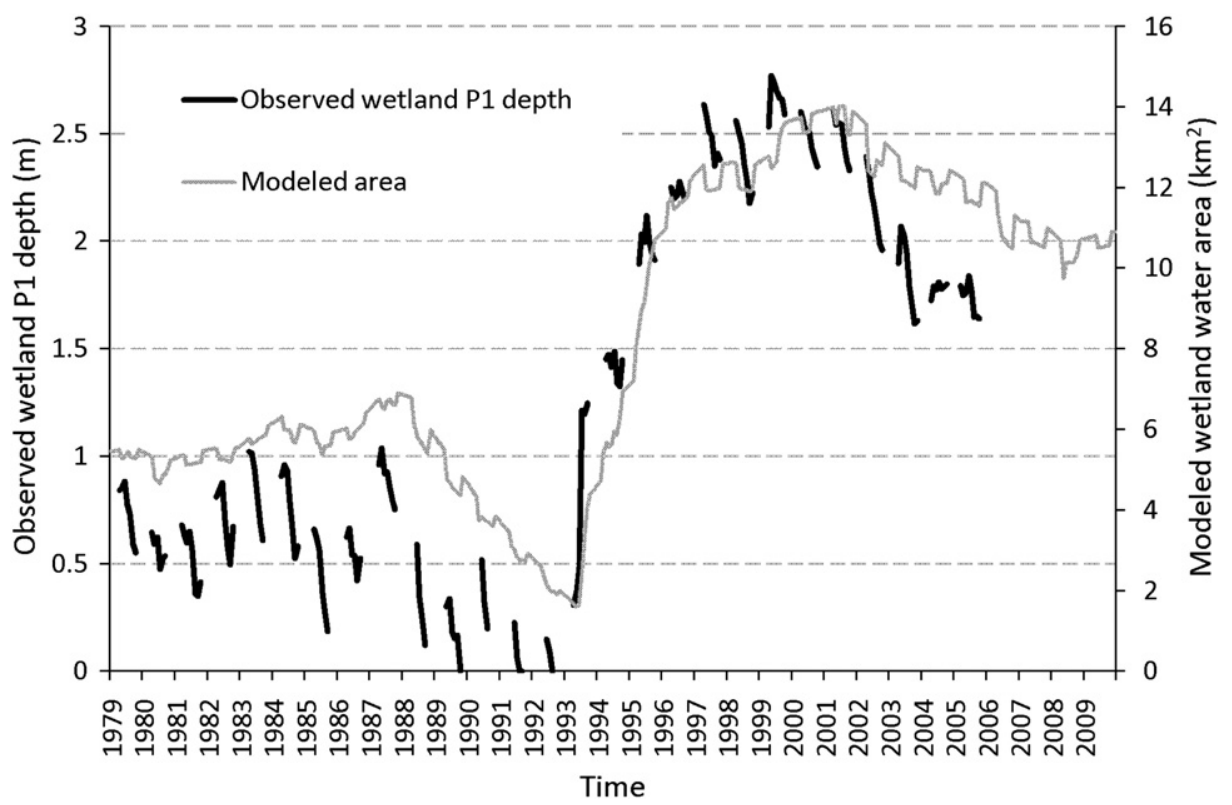

Fig. 13. Comparison of the model-derived wetland water area and the observed water levels of a semi-permanent wetland P1. 


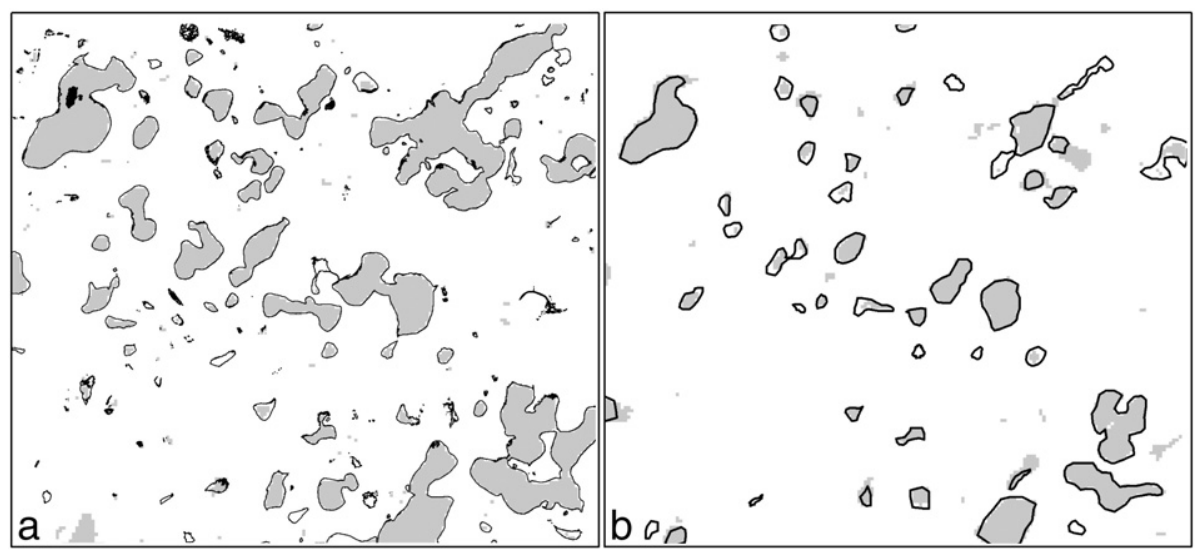

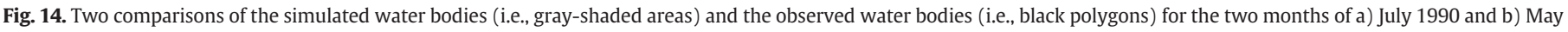

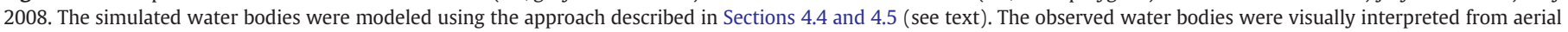
photographs acquired on 28 July 1990 or classified from LiDAR acquired on 17 May 2008. The area of the region is $5.4 \mathrm{~km} \times 4.9 \mathrm{~km}$.

modest single seasonal snowmelt or single heavy rain (Zhang et al., 2009). This underestimation could be further demonstrated in Fig. 14a. Within the preceding $96 \mathrm{~h}$ of 28 July 1990, there was rainfall of $30.56 \mathrm{~mm}$ (see Table 2). Fig. 14a shows our modeled water bodies for July 1990 were mostly smaller than the water from aerial photographs of 28 July 1990.

\section{Discussion}

The water levels in PPR wetlands are influenced by the comprehensive functions of factors of wetland size, basin morphometry, soil permeability, land use, catchment size, topographic position, groundwater flow, wetland drainage patterns, temperature, and precipitation (Niemuth et al., 2010). The relative importance of each of these factors for water accumulation and retention has been studied for only a few wetlands and may vary geographically (Winter, 1989); however, precipitation and temperature are the most important factors leading to substantial changes in the area and number of wetlands from year to year (Larson, 1995), but they alone would be insufficient to explain annual wetland water conditions in the PPR (Niemuth et al., 2010). PDSI was principally developed based on temperature and precipitation and should contain useful information for the water surface of the PPR wetlands, but PDSI has several drawbacks (Alley, 1984; Karl \& Knight, 1985) and has often been used without rigorous evaluation (Dai et al., 2004). Remote sensing images are snapshots of actual landscape conditions and can depict the spatial

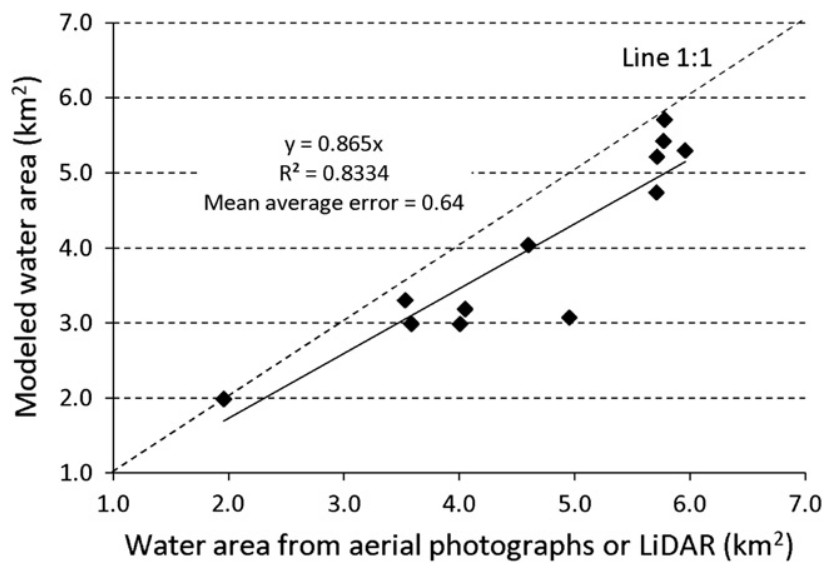

Fig. 15. Comparison of water areas between modeling (including large and small wetlands) and visual interpretation. distribution of water bodies well, enabling us to avoid considering too many confounding factors; however, remote sensing has deficiencies in terms of spatial resolution, cloud cover, coverage, and a short historical record. Considering the advantages and disadvantages of PDSI and remote sensing, we proposed a new index WWAI from PDSI for exploring the regression with Landsat-derived water bodies and modeling the spatial distribution. Taking full advantage of over 100 years of PDSI, static NWI baseline, and limited Landsat images, we could model the wetland water distribution for 100 years at a time step of 1 month.

Our study is distinguished from others in several aspects. First, our products depict how individual wetlands vary in time and space or as a function of water regime or local conditions. Second, we can provide insight into the intra-seasonal variation of water areas in wetlands, so the duration that water persists in wetland basins each year can be identified. Third, we can model the water distribution, even if there are no cloud-free satellite images. Fourth, Zhang et al. (2009) stated that despite the availability of hydrological and meteorological records for the early 1900s, the fate of the pothole lakes during the Dust Bowl drought is not well known. Therefore, they used the aerial photographs of 29 July 1939 to measure the water area of lakes and wetlands in order to define the size structure of the wetland system. Using our approach, however, we do not necessarily rely on satellite records back to early 1900 s, but we can still technically model the spatial distribution of wetland water bodies using the available PDSI

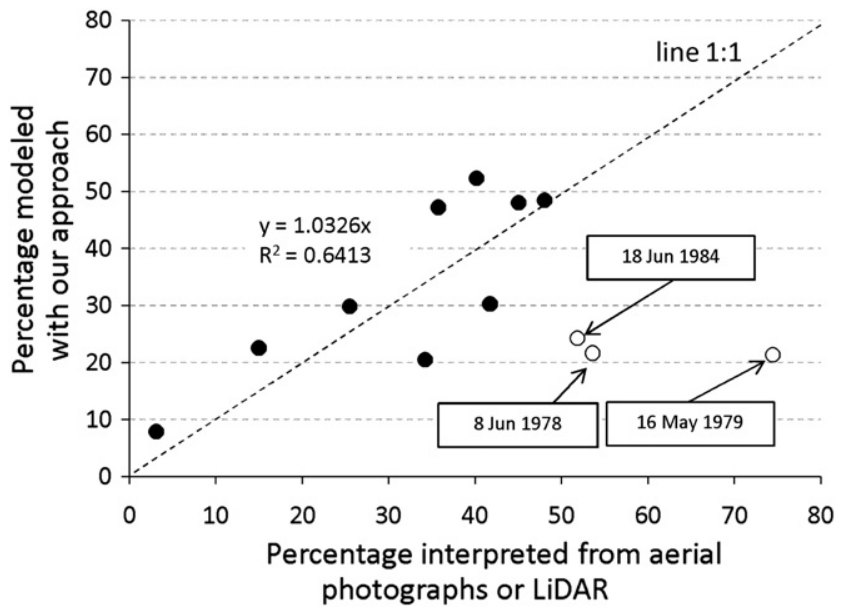

Fig. 16. Small wetlands comparison. Three outliers that show the modeling underestimation due to rainfall (see text) were excluded in regression analysis. 
records. Fifth, Landsat cannot detect small wetlands. Small wetlands areas are dependent upon the water availability over the previous months. The areas of smaller wetlands are profoundly affected seasonally by the spring snowmelt and evaporation and can decline to a much greater extent than larger wetlands with the temperature and evaporation rate rising dramatically from spring to summer (Zhang et al., 2009). By comprehensively considering NWI, PDSI, and large wetland water-filled percentage, we could use a similar approach of Niemuth et al. (2010) to model small wetlands.

End users (such as those from state, local, or Federal agencies) could similarly apply our approach to assess both inter-annual and intra-annual water extent change. The products could be useful for applications ranging from waterfowl management to agricultural production. Furthermore, our approach could be used for short-term (months to several years) water extent prediction. For example, if some users assume or predict the climate of the coming months or years reasonably, we can calculate the corresponding PDSI and then model the water distribution. This information might be important for flood water mitigation or waterfowl adaptive management. However, users should be aware of some deficiencies.

The first deficiency is about short-term weather events. A severe thunderstorm can create large surface runoff or even flash flooding but may leave the subsurface soil dry (Dai et al., 2004). The water extent may increase rapidly during this kind of rainfall event and then decrease due to soil infiltration and ground water recharge. Our monthly product cannot capture this short-term phenomenon, as demonstrated in Figs. 14 and 16. One possible solution is to use a shorter interval such as weekly PDSI. Another solution, which we are now studying, is to use hydrological models to simulate water dynamics at landscape level at shorter intervals (e.g., daily) based on recent LiDAR work of Huang et al. (2011). Integrating a high-resolution digital elevation model with hydrological modeling will enable us to understand the mechanisms responsible for the spatial distribution of water bodies; it will also help us informatively distinguish among wetlands with different water regimes, enhancing the gained knowledge of classifying the hydrologic function of Prairie Potholes with Landsat and GIS (Rover et al., 2011).

The second deficiency is about human management and wetlands detection failure. Wetland drainage, which began with European settlement, resulted in a significant loss of potholes. Some of the wetlands have been recently restored under different programs (Johnson et al., 2008). Our modeling result is based on the water bodies detected by available Landsat records. Clearly, the wetland change due to human activities cannot be completely reflected in our products. Furthermore, a wetland comprised of multiple NWI wetland zones could be identified by Landsat; however, some point and linear wetlands identified by the NWI might fail detection by Landsat or modeling by the $\mathrm{P}_{\mathrm{s}}$ approach. It may be necessary that NWI data are processed to wetland basins following the protocol described in Johnson and Higgins (1997) and Niemuth et al. (2010).

The third deficiency is about the extrapolating from this pilot study to the entire PPR. The area of the PPR is vast and exhibits considerable spatial and temporal variability. For example, droughts/deluges do not appear to be synchronous and the spatial distribution of wetlands of varying size and type are not uniform (Millett et al., 2009); this reduces our ability to generalize relationships across the entire PPR. Due to the variability, the coefficients developed in our $196 \mathrm{~km}^{2}$ pilot study area may need calibration and optimization in another region. During the process of parameter determination, some coefficients such as the 14 (i.e., the average ratio of upland catchment and wetland area) can be correspondingly altered using existing NWI datasets. Some other coefficients (e.g., a, b, c, and d in Fig. 7), however, can be determined by some mathematical model calibration approaches (e.g., the maximum correlation through iterative computation used in our study) and thus objectiveness can be reduced (Janssen \& Heuberger, 1995). Despite the need of coefficients calibration for another region, the conceptual model developed in our study (i.e., developing WWAI with PDSI drawbacks taken into account, modeling spatial distribution of water bodies with two baseline Landsat images, and predicting the area and distribution of small wetlands) should be applicable. The next step is to examine the applicability of our approach in different PDSI climate divisions and finally develop a program for the entire PPR.

\section{Conclusion}

Temperature and precipitation are the most important factors in determining the intra- and inter-annual wetland water extent dynamics in the PPR region. PDSI, which is based on the supplyand-demand concept of the water balance equation with precipitation, potential evapotranspiration, water storage, runoff, and previous conditions taken into account, is very useful for modeling the water change. Nevertheless, due to several PDSI drawbacks such as snow accumulation, runoff, evaporation approximation and so on (Alley, 1984; Karl \& Knight, 1985), PDSI does not directly correlate with Landsat-derived water area well. Because the current wetland water is partly inherited from preceding water conditions, cumulative PDSI is more useful. However, original PDSI must be de-trended to remove the increasing or decreasing trend from the long-term record since PDSI is essentially a water balance index. The de-trended PDSI should be further revised to develop a new index to consider the influence of surface runoff, groundwater recharge, and existing water level. This newly developed wetland water area index was highly correlated with Landsat-derived water area with $\mathrm{R}^{2}$ measured up to 0.90 . Due to successful regression, we could predict the monthly water area for 100 years, capturing the inter- and intra-annual change. A water allocation model with two Landsat images serving as a baseline could be applied to model the spatial distribution of water bodies at a resolution of $30 \mathrm{~m}$. However, small wetlands (those less than $0.8 \mathrm{ha}$ ) could not be detected by Landsat; therefore, an additional procedure for integrating the NWI baseline with PDSI was necessary to model the small wetlands dynamics with $\mathrm{R}^{2}$ measured around 0.64 . After all wetlands are combined, the comparison with 12 aerial photographs and LiDAR shows the $\mathrm{R}^{2}$ could measure up to 0.83 with a mean average error of $0.64 \mathrm{~km}^{2}$. Although our products cannot capture the short-term water change caused by intensive rainstorm events and wetland drainage or restoration caused by human activities, the major changes of wetland water surface were successfully simulated. Our products could be useful for applications ranging from waterfowl management to agricultural production. The future study plan is to test the feasibility of our approach in several areas of the PPR with different climate conditions before the methodology is applied to the entire PPR.

\section{Acknowledgments}

This work was supported by U.S. Department of Agriculture's Conservation Effects Assessment Program (CEAP)-Wetlands, the U.S. Geological Survey's Geographic Analysis and Monitoring (GAM) and the Global Change Research Programs. The authors greatly thank Jennifer Rover for providing Landsat data, Craig Walters and Thomas Adamson for revising the English, and Drs. Xuexia Chen and Yinxing Gu for comments on the early version of this manuscript. We thank three anonymous reviewers for providing their invaluable, thoughtful, and constructive comments and suggestions for the manuscript's improvement. Any use of trade, product, or firm names is for descriptive purposes only and does not imply endorsement by the U.S. Government.

\section{References}

Alley, W. M. (1984). The Palmer Drought Severity Index: Limitations and assumptions. Journal of Climate and Applied Meteorology, 23, 1100-1109.

Batt, B. D. J., Anderson, M. G., Anderson, C. D., \& Caswell, F. D. (1989). Use of prairie potholes by North American ducks. In A. G. van der Valk (Ed.), Northern prairie wetlands (pp. 204-227). Ames, USA: Iowa State University. 
Beeri, O., \& Phillips, R. L. (2007). Tracking palustrine water seasonal and annua variability in agricultural wetland landscapes using Landsat from 1997 to 2005 Global Change Biology, 13(4), 897-912.

Bragg, T. B. (1995). The physical environment of Great Plains grasslands. In A. Joern, \& K H. Keeler (Eds.), The changing prairie: North American grasslands (pp. 49-81). New York: Oxford University Press.

Carroll, R. W., Pohll, G. M., Tracy, J., Winter, T., \& Smith, R. (2005). Simulation of a semipermanent wetland basin in the Cottonwood Lake Area, East-Central North Dakota. Journal of Hydrology Engineering, 1(10), 70-84.

Chander, G., Markham, B. L., \& Helder, D. L. (2009). Summary of current radiometric calibration coefficients for Landsat MSS, TM, ETM+, and EO-1 ALI sensors. Remote Sensing of Environment, 113, 893-903.

Dahl, T. E., \& Johnson, C. E. (1991). Status and trends of wetlands in the conterminous United States, mid-1970s to mid-1980s. Washington DC: US Department of the Interior, Fish and Wildlife Service.

Dai, A., Trenberth, K. E., \& Qian, T. (2004). A global dataset of Palmer Drought Severity Index for 1870-2002: Relationship with soil moisture and effects of surface warming. Journal of Hydrometeorology, 5(6), 1117-1130.

Diaz, H. F. (1983). Some aspects of major dry and wet periods in the contiguous United States, 1895-1981. Journal of Climate and Applied Meteorology, 22, 3-16.

Diaz, H. F. (1986). An analysis of twentieth century climate fluctuations in northern North America. Journal of Climate and Applied Meteorology, 25, 1625-1657.

Dracup, J. A. (1991). Drought monitoring. Stochastic Hydrology and Hydraulics, 5(4), 261-266.

Duvick, D. N., \& Blasing, T. J. (1981). A dendroclimatic reconstruction of annual precipitation amounts in Iowa since 1680. Water Resources Research, 17(4), 1183-1189.

Eisenlohr, W. S., Jr. (1966). Water loss from a natural pond through transpiration by hydrophytes. Water Resources Research, 2(3), 443-453.

Euliss, N. H., Jr., \& Mushet, D. M. (1996). Water-level fluctuation in wetlands as a function of landscape condition in the prairie pothole region. Wetlands, 16(4), 587-593.

Fang, X., \& Pomeroy, J. W. (2008). Drought impacts on Canadian prairie wetland snow hydrology. Hydrological Process, 22(15), 2858-2873.

Fenneman, N. M. (1931). Physiography of Western United States. New York; London: McGraw-Hill Book Co. 534 pp.

Frazier, P. S., \& Page, J. P. (2000). Water body detection and delineation with Landsat TM data. Photogrammetric Engineering and Remote Sensing, 66(12), 1461-1468.

Gilmer, D., Work, E., Colwell, J., \& Rebel, D. (1980). Enumeration of Prairie wetlands with Landsat and aircraft data. Photogrammetric Engineering and Remote Sensing, 46 (5), 631-634.

Ecosystem services derived from wetland conservation practices in the United States prairie pothole region with an emphasis on the U.S. Gleason, R. A., Laubhan, M. K., \& Euliss, N. H. (Eds.). (2008). U.S. Geological SurveyReston, VA, USA: Department of Agriculture Conservation Reserve and Wetlands Reserve Programs Professional Paper 1745.

Gleason, R. A., \& Tangen, B. A. (2008). Ecosystem services derived from wetland conservation practices in the United States prairie pothole region with an emphasis on the U.S. (Chapter D. pp 31-37). In R. A Gleason, M. K. Laubhan, \& N. H. EulissJr. (Eds.), Floodwater storage. U.S. Geological Survey. Reston, VA, USA: Department of Agriculture Conservation Reserve and Wetlands Reserve Programs Professional Paper 1745.

Gleason, R. A., Tangen, B. A., Browne, B. A., \& Euliss, N. H., Jr. (2009). Greenhouse gas flux from cropland and restored wetlands in the Prairie Pothole Region. Soil Biology and Biochemistry, 41, 2501-2507.

Hord, R. M. (1982). Digital image processing of remotely sensed data. New York: Academic Press.

Huang, S., Young, C., Feng, M., Heidemann, K., Cushing, M., Mushet, D. M., et al. (2011) Demonstration of a conceptual model for using LiDAR to improve the estimation of floodwater mitigation potential of Prairie Pothole Region wetlands. Journal of Hydrology, 405, 417-426.

Janssen, P. M., \& Heuberger, P. C. (1995). Calibration of process-oriented models Ecological Modelling, 83(1-2), 55-66.

Jensen, J. R. (1986). Introductory digital image processing. New Jersey: Prentice-Hall $379 \mathrm{pp}$.

Ji, L., Zhang, L., \& Wylie, B. (2009). Analysis of dynamic of thresholds for the Normalized Difference Water Index. Photogrammetric Engineering and Remote Sensing, 75(11), $1307-1317$

Johnson, R. R., \& Higgins, K. F. (1997). Wetland resources of eastern South Dakota. South Dakota State University: Brookings 102 pp.

Johnson, W. C., Boettcher, S. E., Poiani, K. A., \& Guntenspergen, G. (2004). Influence of weather extremes on the water levels of glaciated prairie wetlands. Wetlands, 24(2), 385-398.

Johnson, W. C., Millett, B. V., Gilmanov, T., Voldseth, R. A., Guntenspergen, G. R., \& Naugle, D. E. (2005). Vulnerability of Northern Prairie wetlands to climate change. Bioscience, 55(10), 863-872.

Johnson, R. R., Oslund, F. T., \& Hertel, D. R. (2008). The past, present, and future of prairie potholes in the United States. Journal of Soil and Water Conservation, 63(3), 84A Research Library.

Johnson, W. C., Werner, B., Guntenspergen, G. R., Voldseth, R. A., Millett, B., Naugle, D. E. et al. (2010). Prairie wetland complexes as landscape functional units in a changing climate. Bioscience, 60(2), 128-140.
Karl, T. R., \& Knight, R. W. (1985). Atlas of monthly Palmer Hydrological Drought Indices (1931-1983) for the contiguous United States. Historical Climatology Series 3-7. Asheville, North Carolina: National Climatic Data Center.

Karl, T. R., \& Koscielny, A. J. (1982). Drought in the United States: 1895-1981. International Journal of Climatology, 2(4), 313-329.

Karl, T. R., \& Riebsame, W. E. (1984). The identification of 10 to 20 year temperature and precipitation fluctuations in the contiguous United States. Journal of Applied Meteorology, 23(6), 950-966.

LaBaugh, J. W., Winter, T. C., \& Rosenberry, D. O. (1998). Hydrologic functions of prairie wetlands. Great Plains Research, 8, 17-37.

Larson, D. L. (1995). Effects of climate on numbers of Northern Prairie wetlands. Climatic Change, 30(2), 169-180.

Liu, G., \& Schwartz, F. W. (2011). An integrated observational and model-based analysis of the hydrologic response of prairie pothole systems to variability in climate. Water Resources Research, 47, W02504, doi:10.1029/2010WR009084.

Millar, J. B. (1971). Shoreline-area ratio as a factor in rate of water loss from small sloughs. Journal of Hydrology, 14(3-4), 259-284.

Millett, B., Johnson, W. C., \& Guntenspergen, G. (2009). Climate trends of the North American prairie pothole region 1906-2000. Climatic Change, 93(1-2), 243-267.

Niemuth, N. D., Wangler, B., \& Reynolds, R. E. (2010). Spatial and temporal variation in wet area of wetlands in the prairie pothole region of North Dakota and South Dakota. Wetlands, 30(6), 1053-1064.

Ozesmi, S. L., \& Bauer, M. E. (2002). Satellite remote sensing of wetlands. Wetlands Ecology and Management, 10(5), 381-402.

Palmer, W. C. (1965). Meteorological drought. Research Paper No. 45. Washington DC: U.S. Department of Commerce Weather Bureau.

Parkhurst, R. S., Winter, T. C., Rosenberry, D. O., \& Sturrock, A. M. (1998). Evaporation from a small prairie wetland in the Cottonwood Lake area, North Dakota: an energy budget study. Wetlands, 18(2), 272-287.

Pospahala, R. S., Anderson, D. R., \& Henny, C. J. (1974). Population ecology of the mallard: II. Breeding habitat conditions, size of the breeding populations, and production indices. : U.S. Fish and Wildlife Service Resource Publication 73 pp.

Rosenberry, D. O., Stannard, D. I., Winter, T. C., \& Martinez, M. L. (2004). Comparison of 13 equations for determining evapotranspiration from a prairie wetland, Cottonwood Lake area, North Dakota, USA. Wetlands, 24(3), 483-497.

Rover, J., Wright, C. K., Euliss, N. H., Jr., Mushet, D. M., \& Wylie, B. K. (2011). Classifying the hydrologic function of Prairie Potholes with remote sensing and GIS. Wetlands, 31(2), 319-327.

Rundquist, D., Lawson, M., Queen, L., \& Cerveny, R. (1987). The relationship between summer-season rainfall events and lake-surface area. Water Resources Bulletin, 23 (3), 493-508

Sethre, P. R., Rundquist, B. C., \& Todhunter, P. E. (2005). Remote detection of prairie pothole ponds in the Devils Lake Basin, North Dakota. GIScience \& Remote Sensing, 42(4), 277-296.

Smith, D. I., Hutchinson, M. F., \& McArthur, R. J. (1993). Australian climatic and agricultural drought: Payments and policy. Drought Network News, 5(3), 11-12.

Sorenson, L. G., Goldberg, R., Root, T. L., \& Anderson, M. G. (1998). Potential effects of global warming on waterfowl populations breeding in the Northern Great Plains. Climatic Change, 40(2), 343-369.

Stewart, R. E., \& Kantrud, H. A. (1971). Classification of natural ponds and lakes in the glaciated prairie region. U.S. Fish and Wildlife Service Resource Publication 92. Washington DC: U.S. Government Printing Office.

Thornthwaite, C. W. (1948). An approach toward a rational classification of climate. Geographical Review, 38(1), 55-94.

van der Kamp, G., \& Hayashi, M. (2009). Groundwater-wetland ecosystem interaction in the semiarid glaciated plains of North America. Hydrogeology Journal, 17(1), 203-214.

van der Valk, A. G. (2005). Water-level fluctuations in North American prairie wetlands. Hydrobiologia, 539, 171-188.

Winter, T. C. (1989). Hydrologic studies of wetlands in the northern prairie. In A. G. van der Valk (Ed.), Northern prairie wetlands. Ames, Iowa: Iowa-State University Press.

Winter, T. C., \& LaBaugh, J. W. (2003). Hydrologic considerations in defining isolated wetlands. Wetlands, 23(3), 532-540.

Winter, T. C., \& Rosenberry, D. O. (1995). The interaction of ground water with Prairie Pothole wetlands in the Cottonwood Lake area, east-central North Dakota, 19791990. Wetlands, 15(3), 193-211.

Winter, T. C., \& Rosenberry, D. O. (1998). Hydrology of Prairie Pothole wetlands during drought and deluge: A 17-year study of the Cottonwood Lake wetland complex in North Dakota in the perspective of longer term measured and proxy hydrological records. Climatic Change, 40(2), 189-209.

Woo, M. K., \& Winter, T. C. (1993). The role of permafrost and seasonal frost in the hydrology of northern wetlands in North America. Journal of Hydrology, 141(1-4), 5-31.

Woodhouse, C. A., \& Overpeck, J. T. (1998). 2000 years of drought variability in the central United States. Bulletin of the American Meteorological Society, 79(12), 2693-2714.

Work, E. A., Jr., Gilmer, D. S., \& Klett, A. T. (1974). Utility of ERTS for monitoring the breeding habitat of migratory waterfowl. Proceedings of the Third Earth Resources Technology Satellite-1 Symposium, 1. (pp. 10-14).

Zhang, B., Schwartz, F. W., \& Liu, G. (2009). Systematics in the size structure of prairie pothole lakes through drought and deluge. Water Resources Research, 45(w044210), 12. 